\title{
()
}

European Bank

for Reconstruction and Development

\section{European financial integration and the financing of local businesses in the new EU member states}

\author{
Ulrich Volz
}

\begin{abstract}
This paper explores the degree of financial market integration between the new and old EU member states. It also considers the likely effects of the ongoing integration process on the new members' financial sectors. In particular, the paper discusses the implications of the high concentration of financial services and the dominance of foreign-owned institutions for the provision of financial services to small and medium-sized enterprises (SMEs) in the ten accession countries. Using enterprise data on 2,427 firms, the paper finds that access to finance still constitutes a major problem for business development and that financing conditions are considerably more difficult for SMEs than for larger entities.
\end{abstract}

Keywords: financial integration, large and foreign banks, banking competition, SME finance

JEL Classification Number: G21, G3, O16, P34

Address for Correspondence: HWWA, World Economy Department, Neuer Jungfernstieg 21, 20347 Hamburg, Germany.

Phone: +49 4042834 276; Fax: +49 4042834 451;

E-mail: ulrich.volz@hwwa.de.

Ulrich Volz is at the Free University of Berlin and the Hamburg Institute of International Economics (HWWA).

The views and opinions expressed are those of the author only and do not necessarily reflect the views of the European Bank for Reconstruction and Development. The paper was written during a stay at the EBRD's Office of the Chief Economist from September 2003 - May 2004. Funding by the German Academic Exchange Service and the German Merit Foundation is gratefully acknowledged. The author would like to thank the Office of the Chief Economist for its great hospitality and support and Alan Bevan, Victoria Chick, Chris Cviic, Ralph De Haas, Elisabetta Falcetti, Steven Fries, Tanja Lysenko, Peter Sanfey and Anita Taci for fruitful discussions and valuable comments and suggestions.

The working paper series has been produced to stimulate debate on the economic transformation of central and eastern Europe and the CIS. Views presented are those of the authors and not necessarily of the EBRD. 


\section{INTRODUCTION}

On 1 May 2004, eight east European transition countries - the Czech Republic, Estonia, Hungary, Latvia, Lithuania, Poland, the Slovak Republic and Slovenia - joined the European Union (EU). Bulgaria and Romania hope to become members in 2007. In many respects, this poses great challenges for both the new member states and the EU as a whole, one of which is the future shape of the European financial system.

The aim of this paper is to consider the likely effects of the ongoing integration process for the new members' financial sectors. In particular, the paper discusses the concentration of financial services and the dominance of foreign-owned financial institutions in providing financial services to small and medium-sized enterprises in the accession countries (ACs).

Financial integration is understood as financial markets becoming increasingly intertwined and alike. While integration is likely to spur the efficiency of the financial intermediaries and markets of financially less developed countries, this paper argues that the restructuring of the ACs' financial sectors could have serious effects for the financing of small local businesses. The reasoning is as follows: competition within financial markets does not produce results similar to those in ordinary business. Instead, competition can lead to a concentration in banking (Chick 2000). The central importance of banking is its relationship with other businesses. If the banking sector becomes more concentrated and dominated by foreign banks - a process that can already be observed in the ACs - large companies will become favoured recipients of loans and other services whereas small and medium companies, especially in peripheral regions, will find it more difficult to get funding. While larger firms will find much more favourable financing conditions as they can raise funds both domestically and overseas, the majority of small and medium-sized firms might not be able to do so. Since these firms are important for economic growth and need to raise capital, this could prove to be a costly outcome for the ACs.

Using enterprise data on 2,427 firms, this paper finds that access to finance still constitutes a major problem for business development in the ACs. In addition, financing conditions are considerably more difficult for small and medium-sized enterprises than for larger entities. The large-bank barriers hypothesis and the foreign-owned-bank barriers hypothesis (Berger, Klapper and Udell 2001) argue that the way the ACs' banking systems have evolved over the past decade, i.e. the banking systems being dominated by large, foreign-owned banks, could pose serious constraints on the development of small businesses. Further, these businesses may not benefit as much from financial integration as will larger firms.

This paper is structured as follows: the next section briefly discusses the links between financial integration, financial development and economic growth. Section two looks at how the ACs' financial systems have integrated into the EU financial markets. It particularly investigates the role of foreign banks. This is followed by a discussion of potential consequences of the ongoing integration process on the ACs' financial markets and the financing conditions of small businesses in section three. Section four concludes.

\footnotetext{
${ }^{1}$ Throughout this paper, the term "accession countries" is being used for the ten transition countries listed above. Cyprus and Malta who also joined the EU on 1 May 2004 have not been considered.
} 


\section{FINANCIAL INTEGRATION, FINANCIAL DEVELOPMENT AND ECONOMIC GROWTH}

A common presumption in the literature on financial integration is that it spurs financial development in the less financially developed regions or countries of the integrating area. The financial systems and their degree of sophistication should therefore become more similar, in the sense that the less developed financial sectors catch up and move towards the standards of the most financially developed sectors. Financial integration should thus increase the supply of finance in the more backward regions. This should be reflected in an expansion of the national financial systems of these countries (Gianetti et al., 2002).

There are basically two ways by which integration could have an effect on the development of national financial markets. Firstly, financial integration is expected to improve the efficiency of the financial intermediaries and markets of the less financially developed countries. As integration facilitates the actual or potential market entry of foreign institutions to the financially less developed market, domestic institutions will find themselves exposed to increased competitive pressure from more sophisticated and cheaper foreign intermediaries. Foreign institutions may choose to enter the market via direct penetration or cross-border acquisitions of intermediaries. Banks that extend their operations abroad are likely to be among the most efficient in their home country and can be expected to outperform the local banks. This is likely to set new standards in management and efficiency, and enhance the quality and range of financial products offered. Domestic institutions will increasingly face pressure to improve their own efficiency by cost-cutting and organisational restructuring to secure profitability. The competitive pressure should thus erode the local banks' rents and lead to a more efficient financial market with better credit conditions for firms and households.

Secondly, as a rule, financial integration would require an improvement in the regulation and supervision of the national financial market. Issues such as banking supervision, corporate governance, accounting standards and auditing procedures need to be brought in line with best practices in the integrating area to guarantee a "level playing field" (Gianetti et al., 2002, p. 13). An improvement in the regulatory standards of less developed financial markets should not only reduce the vulnerability of these markets, but may also help to promote their development by reducing adverse selection as well as the distortions induced by inadequate regulation.

There is a firm consensus nowadays that a well-functioning financial sector is a precondition for an efficient allocation of resources and the exploitation of an economy's growth potential (Thiel, 2001). While there is still an ongoing debate on the exact transmission channels from finance to economic activity, and its quantitative impact in particular, a large and growing amount of empirical research has documented a robust correlation between finance and growth and a causality running from financial development to economic growth. ${ }^{2}$

The economic literature highlights three main channels by which financial development can affect growth (Pagano, 1993). Firstly, a more efficient financial system reduces the cost of financial intermediation and hence raises the fraction of savings funnelled to investment. The more efficient the transformation of savings into investment, the lesser the loss of resources, and the more savings are channelled towards productive investment (Thiel, 2001, p. 17). Competition and increased efficiency should bring interest-rate margins down, and the availability of credit to firms and households should correspondingly tend to increase.

\footnotetext{
${ }^{2}$ For a survey of the finance-growth nexus and a more detailed discussion see Pagano (1993), Thiel (2001), Gianetti et al. (2002) and Levine (2003).
} 
Secondly, a well-functioning financial sector is a precondition for the efficient allocation of resources, and improvements in financial intermediation may ameliorate the allocation of resources across investment projects. A better trading, hedging and pooling of risks allows the funding of highly profitable, but risky investment projects that would be relinquished otherwise. The more advanced financial systems become, the better they should be able to deal with the problems of asymmetric information that are persistent in financial markets. This should further reduce the cost of financial intermediation. Moreover, a more sophisticated financial sector should be more capable of distinguishing between good and bad investment opportunities, increasing the social marginal productivity of capital (Gianetti et al., 2002, pp. 7-8).

A third way by which financial development could affect economic growth is through influencing households' savings rate. While the effect in the two channels mentioned before is generally positive, it is ambiguous in this case. A higher efficiency of the financial system should yield more favourable return-risk combinations for savers. But it is not clear whether or not the prospects of higher returns or lower risk on savings would induce households to save more, which in turn would stimulate higher economic growth.

In addition to a potentially positive effect on the development of national financial markets, the process of financial integration might also enhance each country's access to the financial markets of other countries of the integration area. In particular, it is quite possible that, as financial integration proceeds, the most financially developed countries will share the services provided by their financial systems with the other integrating countries (Gianetti et al., 2002, p. 14). Economies of scale and external economies may give an incentive to established intermediaries of the more developed markets to provide cross-border loans and other financial services to the firms of less advanced countries. Also, firms of less developed countries might bypass their home country's securities markets and instead seek listings in the major financial centres. 


\section{FINANCIAL INTEGRATION OF THE NEW EU MEMBER STATES INTO THE EU-15's FINANCIAL MARKET}

There are a number of ways to measure financial integration. A summary volume-based measure of international financial integration (Lane and Milesi-Ferretti, 2003, p. 86) is

(1) $I_{F I G D P}=\left(F A_{i t}+F L_{i t}\right) / G D P_{i t}$,

where IFIGDP $P_{i t}$ stands for international financial integration for country $i$ at time $t$ and FA and FL refer to the stocks of aggregate foreign assets and liabilities, respectively. ${ }^{3}$ Figure 1 shows that, according to this broad measure, the ACs' financial integration into the world economy has increased markedly over the past decade (with the exception of Bulgaria where the ratio has been relatively high anyway). We will later see that EU financial markets play a particularly important role in this process.

\section{Figure 1: IFIGDP}

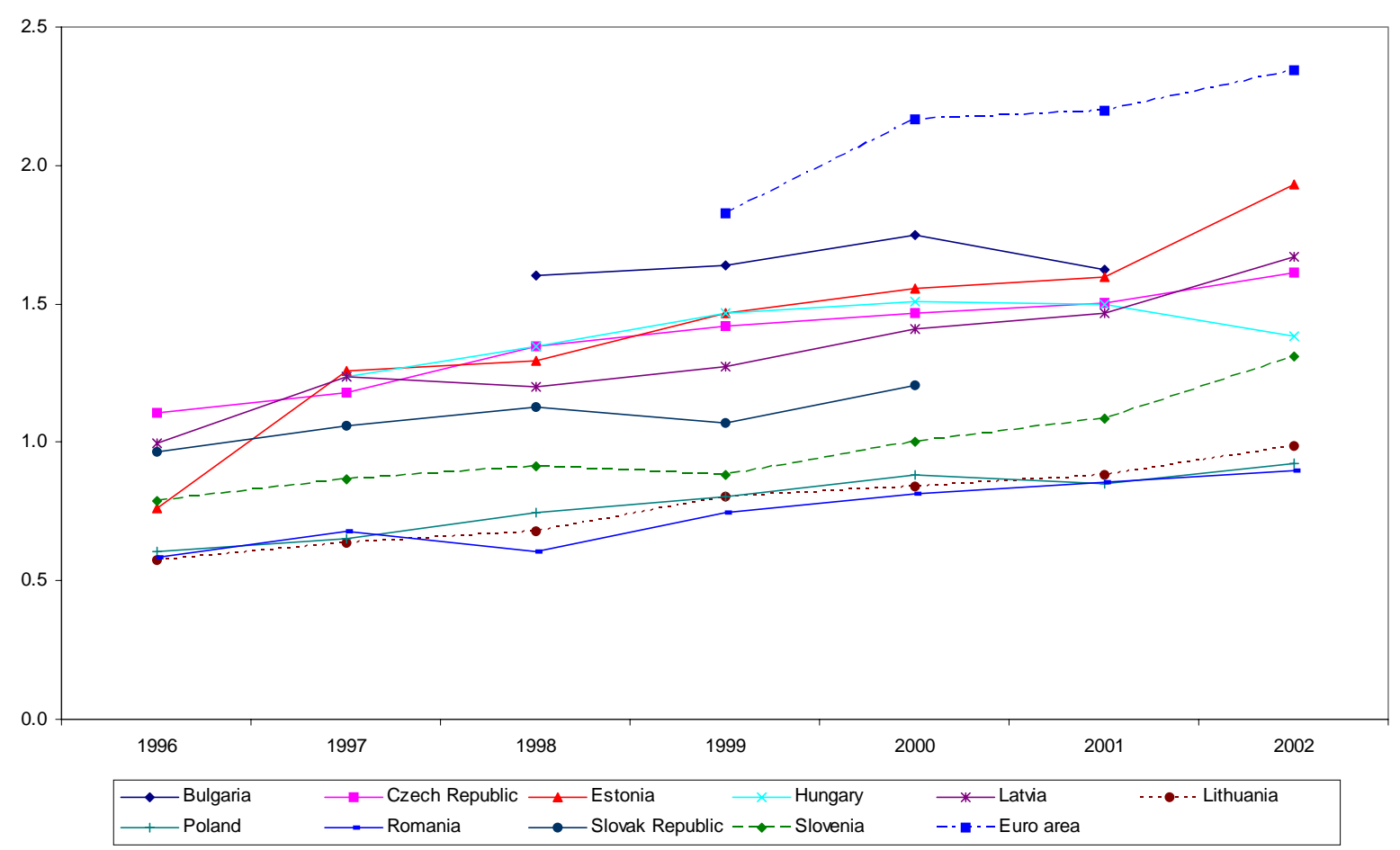

Source: IFS.

The following section aims to measure the degree of integration of the ACs' financial sectors into EU financial markets. This is done by using several quantitative and qualitative indicators proposed in the literature on financial market integration. One difficulty is data availability and reliability, which impedes the application of some more sophisticated methodologies. Given the still relatively low market capitalisation in the ACs, indicators looking at the integration of security markets have only limited explanatory power (especially as the short

\footnotetext{
${ }^{3}$ This data on countries' portfolios of external assets and liabilities - the so-called international investment position - summarise total holdings by domestic residents of financial claims on the rest of the world and non-residents' claims on the domestic economy. External liabilities are divided into four main categories: foreign direct investment, portfolio investment (equity and debt securities), financial derivatives, and other investment (monetary authorities, general government, banks, and other sectors). Assets constitute the same four categories as liabilities, plus official reserves.
} 
time period for which data are available does not allow for extensive statistical analyses). The study will hence focus - although not exclusively - on indicators relating to the banking sectors.

The indicators applied fall into the following five categories:

- indicators relating to the development of the domestic financial sectors

- indicators of stock and bond market integration

- interest rate differentials to analyse the degree of convergence in the money market

- indicators relating to institutional conditions that may induce financial market segmentation (legal and institutional framework)

- indicators unfolding the role of foreign banks.

Throughout the following sections, the EU-15 and the euro area (EU-15 without Denmark, Sweden and the UK) will be used as a benchmark. However, it has to be recognised that western European countries still differ considerably in the degree of financial development and are far from having achieved full integration. Also, financial markets in the EU are subject to change themselves, and taking them as a benchmark therefore implies that this benchmark is a moving target (Padoa-Schioppa, 2001, p. 7).

\subsection{MEASURES OF FINANCIAL DEVELOPMENT}

\subsubsection{SIZE MEASURES}

If financial integration increases the supply of finance in the financially less developed countries of the integrating area, as just discussed, this should be reflected in an expansion of the financial systems of these countries. ${ }^{4}$ The size of national financial systems (relative to GDP) should hence accelerate in the financially less developed countries (Gianetti et al., 2002, p. 12). This requires two qualifications. Firstly, one should not expect financial integration to fully equalise the degree of financial development within the integrating area because institutional, informational and cultural (including language) barriers may prevent market forces to completely level the field. Furthermore, the literature on economic geography and centre-periphery models challenges static equilibrium theory. These models argue that economic integration might not always cause spatial differences to narrow. ${ }^{5}$

Secondly, because financial integration is likely to improve access to other financial markets of the integrating area, domestic clients might choose to "by-pass" the financial market of their home country. If domestic firms and households finance themselves through foreign

\footnotetext{
${ }^{4}$ One qualification needs to be made with respect to the link between financial integration and financial development. While it is reasonable to assume that financial integration spurs financial development, for the reasons discussed in section one, it certainly is not the only reason for financial development. Starting from a very low level of financial development, characterised by monobanking-systems and almost non-existent capital markets, the central and eastern European transition countries have undergone major structural changes in their movement from centrally planned to market-based economies. This process had and still has its own dynamics. Slovenia's banking sector, for example, improved significantly without much financial integration. However, as different regions or countries of the integrating area become more similar during the process of financial integration, the use of measures of financial development as approximations for the degree of integration is sensible.

${ }^{5}$ Theories of geographic dualism actually argue that in some cases regional economic differences might even widen over time. See, for example, the contributions of Myrdal (1957), Krugman (1991) and Thirlwall (2000).
} 
financial markets, this will not show up in measures of domestic financial development. These measures are therefore only a rough indicator of financial integration, and other indicators such as the magnitude of cross-border activity should be looked at (see section 2.5).

One widely used indicator of the size of financial intermediation is the private credit provided by deposit money banks and other institutions, divided by GDP. Figure 2 shows that while the ratio has modestly increased over the years 1999-2002 in most ACs, claims on the private sector are still fairly low, compared with an average of 109 per cent for the euro area for 2002. On average the share of the ACs' domestic private sector credit to GDP amounts to less than a third of that of the euro area.

\section{Figure 2: Private sector credit as a percentage of GDP}

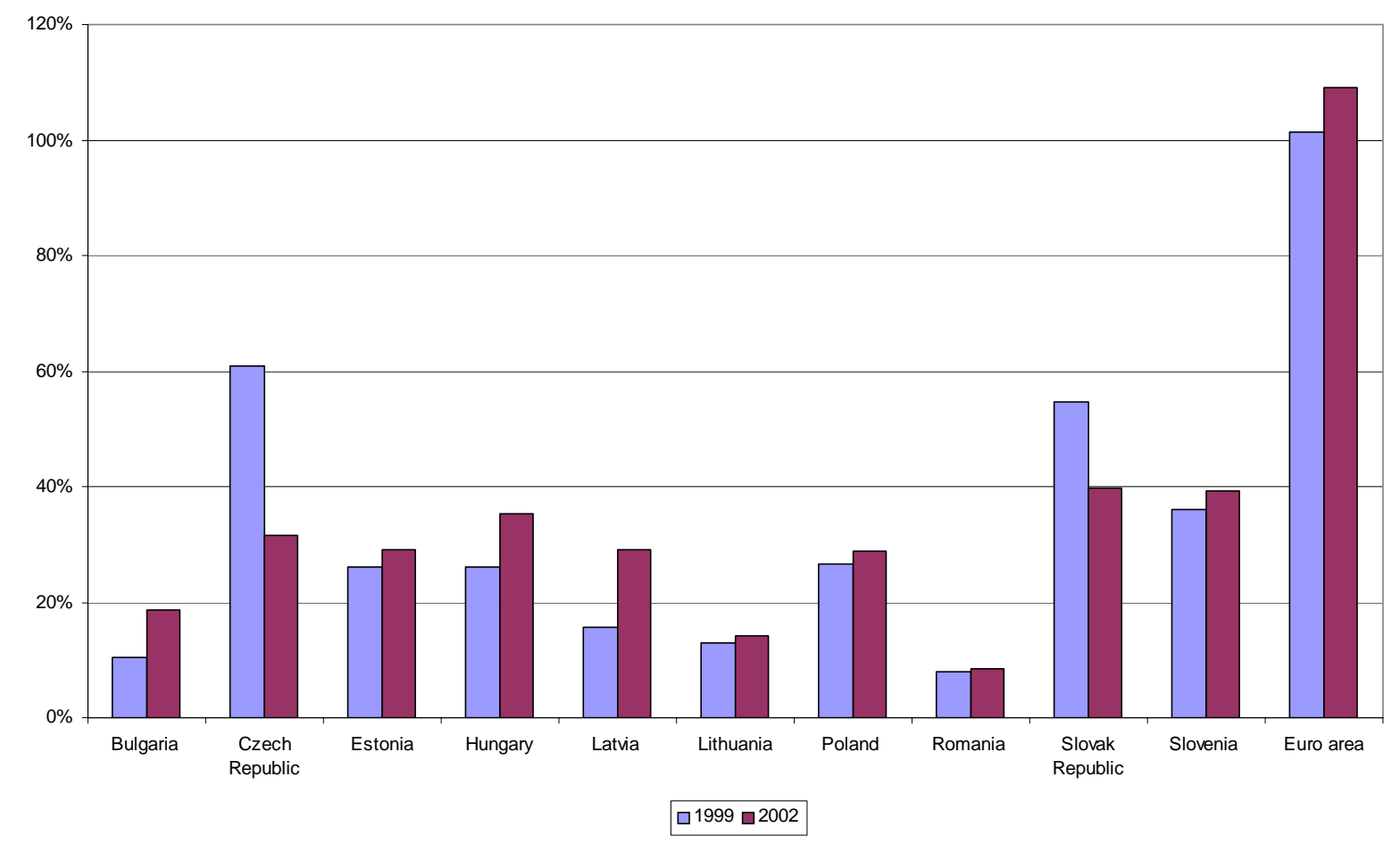

Source: IFS.

The Czech Republic and Slovak Republic experienced a sharp decline in the ratio of private credit to GDP over the three-year period. This decline is primarily due to major restructurings in the banking sectors and a tackling of the problem of non-performing loans. ${ }^{6}$ In the Slovak Republic, for example, the authorities launched a programme at the end of 1999 to recapitalise the three large state-owned banks and address their problem loans. These "big three" had serious problems in loan quality, with non-performing loans accounting for more than half of their total lending. The restructurings reduced the amount of non-performing loans to 18 per cent of the big three's total loans by the end of $2000 .^{7}$ Similarly, the Czech

\footnotetext{
${ }^{6}$ Another major effect was the Czech currency crisis of 1997.

${ }^{7}$ Together with two other smaller state-owned banks, the big three held 47 per cent of the total assets of the national banking sector in 1999. Besides a direct equity infusion of SKK 18.9 billion in December 1999, the restructuring programme included a carve-out of bad assets in two steps at the end of 1999 and June 2000. In total, SKK 105 billion (12 per cent of GDP) was transferred to the Slovak Consolidation Agency and Konsolidačná Banka and replaced by government bonds.
} 
Republic strengthened prudential controls and fostered the transfers of bad loans to a consolidation bank (Konsolidacni banka). This resulted in the share of non-performing loans in the overall loan portfolio of commercial banks decreasing significantly (OECD, 2001, pp. $138-142){ }^{8}$

While these factors largely explain the decrease in outstanding credit to the private sector in the Czech Republic and Slovak Republic, the problem of non-performing loans is also one of the reasons why banks in the other countries were rather reluctant to expand lending to private firms. ${ }^{9}$ Furthermore, in preparing for privatisation, many banks showed risk-averse behaviour.

\section{Figure 3: Stock market capitalisation as a percentage of GDP (end-year)}

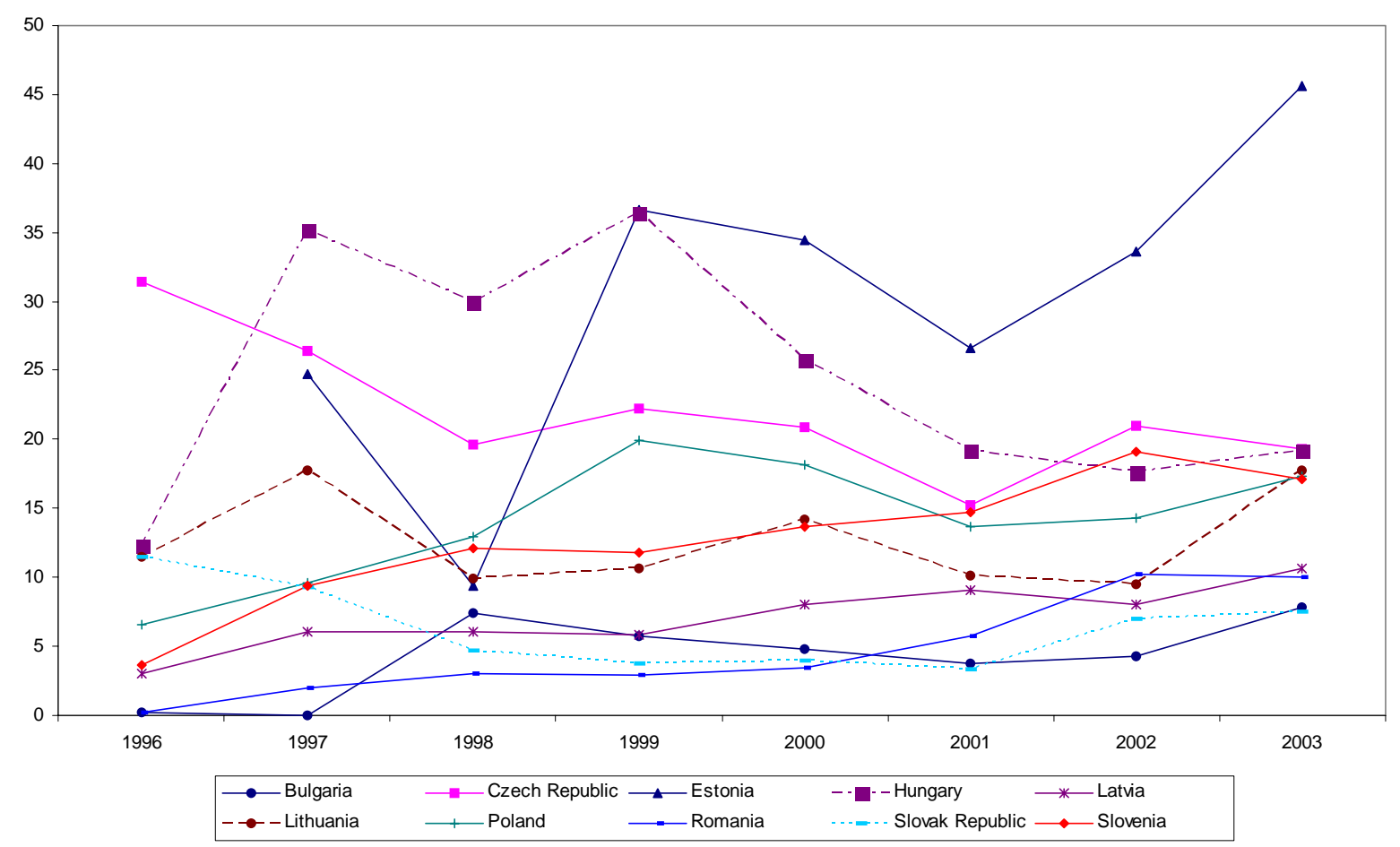

Source: S\&P/IFC Emerging Markets Database.

The most commonly used measures of the size of a country's financial market are its stock and bond market capitalisation in relation to GDP. The more developed a country's capital markets, the easier it should be to fund new investment projects. Figure 3 shows the end-year stock market capitalisation, i.e. the value of listed shares, in the ACs for the years 1996 to 2003. It is apparent that even though marked capitalisation relative to GDP shows some form of increase for most countries, the levels are still very low. Moreover, given the relatively low levels of GDP per capita of the ACs, market capitalisation in absolute terms is particularly low. As an illustration, the total stock market capitalisation of the ACs amounted to US\$ 93,397 million at the end of 2003. This was only 1.2 per cent of the total stock market capitalisation of the western European countries (which, according to the World Federation of Exchanges, was around US\$ 7,820 billion in December 2003). In an international context

Furthermore, to maintain healthy balance sheets in the run-up to privatisation, the financial authorities imposed strict controls on the banks (OECD, 2002, pp. 116-119).

${ }^{8}$ Table 5 in section 2.1.2 provides an overview on the share of non-performing loans relative to total bank loans for all ACs.

${ }^{9}$ The issue of bank lending to the private sector is revisited in detail in section three. 
only the equity markets of Poland and, to a lesser extent, of the Czech Republic and Hungary, play some role (Caviglia et al., 2002, p. 21). ${ }^{10}$

Similarly, the role of domestic bond markets has been rather limited. As with equity markets, only the Polish, Czech and Hungarian bond markets play some role in an international context. The size of the ACs' domestic bond markets in relation to GDP is still fairly small. This is largely due to relatively low levels of outstanding government securities, a result of low government debt. Gross total government debts relative to GDP range from a mere 5 per cent in Estonia to 58 per cent in Hungary in 2003. ${ }^{11}$ The relatively low level of government securities that could serve as a benchmark for corporate bonds is commonly regarded as a major constraint to the development of the corporate bond market.

\section{Figure 4: Spread between lending and deposit rate (in per cent)}

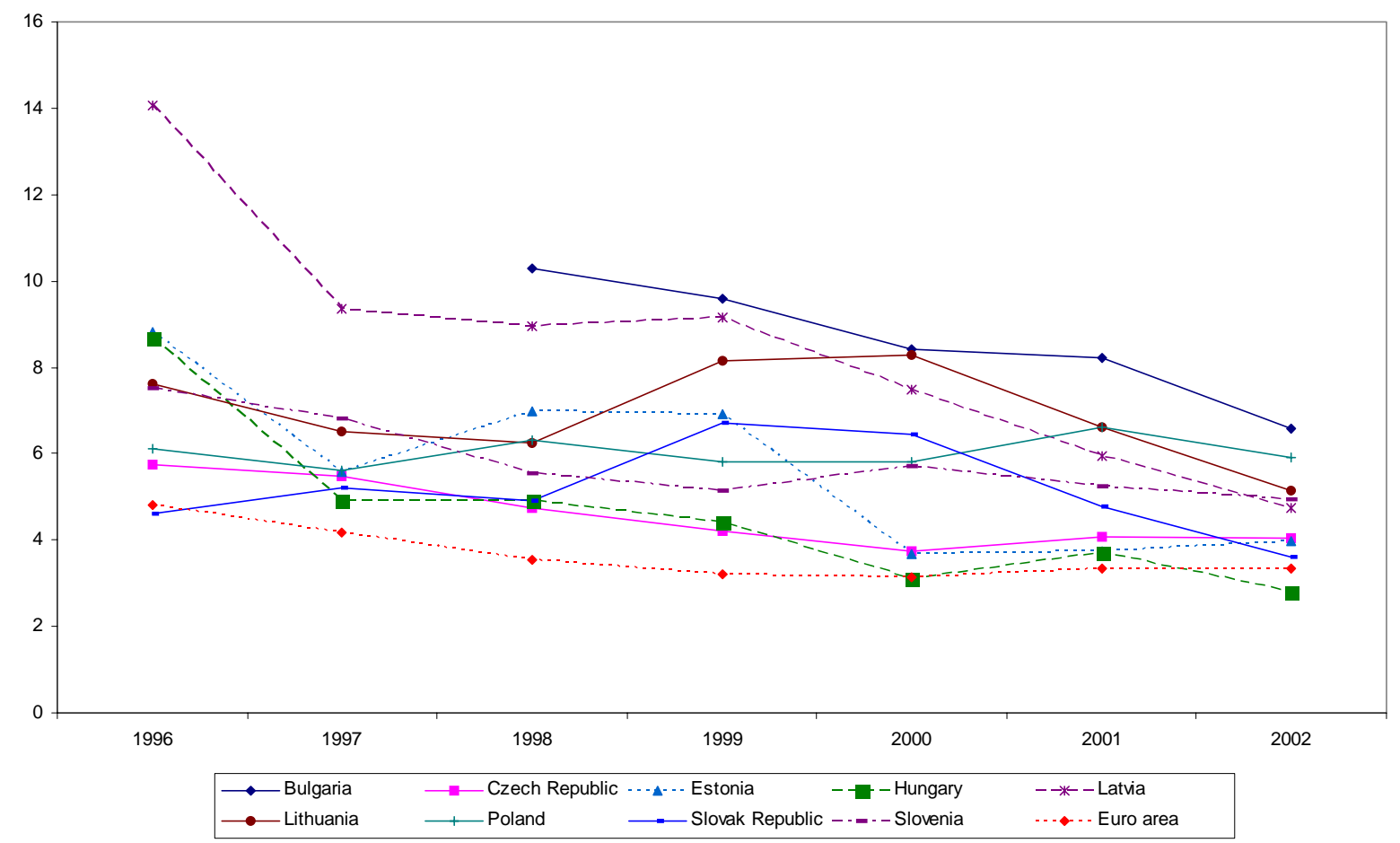

Source: IFS.

Note: Data for Romania are not available.

\subsubsection{EFFICIENCY MEASURES}

A second kind of indicator used to describe financial development relates to the efficiency with which funds are channelled to investment projects (Gianetti et al., 2002, p. 10). Two commonly used efficiency measures are the spread between lending and deposit rates and the share of overhead costs in the bank's total assets. Both are approximations of the costs of

\footnotetext{
${ }^{10}$ With a market capitalisation of US\$ 36,723 million at the end of 2003, the size of the Polish stock market is comparable to the size of the smallest euro area stock market (Luxembourg with a market capitalisation of US\$ 37,333 million). Market capitalisation in the Czech Republic is US\$ 17,232 million and US\$ 16,689 million in Hungary. The markets of the remaining ACs (with an average stock market capitalisation of US $\$ 3,251$ million) are negligible in an international context (S\&P/IFC).

${ }^{11}$ The unweighted average of 32 per cent for all ACs is well below the debt ratio of 60 per cent required for membership in the European Monetary Union.
} 
financial intermediation. Other indicators include a banking sector's average return on assets, the average return on equity, and the amount of non-performing loans. ${ }^{12}$

Figure 4 and table 1 show a general downside trend in the spreads in most countries, indicating that banks in the ACs have significantly improved their efficiency in financial intermediation in recent years. Hungary and the Slovak Republic have already converged to the level of the euro area, and Estonia and the Czech Republic have come very close as well.

Table 1: Spread between lending and deposit rate (in per cent)

\begin{tabular}{lcccccccc}
\hline & $\mathbf{1 9 9 6}$ & $\mathbf{1 9 9 7}$ & $\mathbf{1 9 9 8}$ & $\mathbf{1 9 9 9}$ & $\mathbf{2 0 0 0}$ & $\mathbf{2 0 0 1}$ & $\mathbf{2 0 0 2}$ & $\mathbf{2 0 0 3}$ \\
\hline \hline Bulgaria & na & na & 10.3 & 9.6 & 8.4 & 8.2 & 6.6 & 5.9 \\
Czech Republic & 5.8 & 5.5 & 4.7 & 4.2 & 3.7 & 4.1 & 4.0 & 3.9 \\
Estonia & 8.8 & 5.6 & 7.0 & 6.9 & 3.7 & 3.8 & 4.0 & 3.1 \\
Hungary & 8.7 & 4.9 & 4.9 & 4.4 & 3.1 & 3.7 & 2.8 & na \\
Latvia & 14.1 & 9.4 & 9.0 & 9.2 & 7.5 & 5.9 & 4.7 & 2.4 \\
Lithuania & 7.6 & 6.5 & 6.2 & 8.2 & 8.3 & 6.6 & 5.1 & 4.6 \\
Poland & 6.1 & 5.6 & 6.3 & 5.8 & 5.8 & 6.6 & 5.9 & na \\
Slovak Republic & 4.6 & 5.2 & 4.9 & 6.7 & 6.4 & 4.8 & 3.6 & 3.1 \\
Slovenia & 7.5 & 6.8 & 5.6 & 5.1 & 5.7 & 5.2 & 4.9 & 4.8 \\
Euro area & 4.8 & 4.2 & 3.5 & 3.2 & 3.2 & 3.3 & 3.3 & na \\
\hline Sourcei
\end{tabular}

Source: IFS.

Note: Data for Romania are not available.

Tables 2-4 show the overhead costs of banks as a percentage of total banking assets, the average return on assets (ROA), and the average return on equity (ROE) respectively. ${ }^{13} \mathrm{~A}$ distinction is made between foreign-owned banks (FB) and domestic-owned banks (DB). As expected, foreign-owned banks are more efficient than domestic-owned banks. ${ }^{14}$ This may be due to "cherry-picking", i.e. foreign banks acquiring the most efficient banks, or due to banking and managing experience foreign banks bring with them and transfer to their subsidiaries.

\footnotetext{
${ }^{12}$ For a more elaborate analysis of cost efficiency of banks at bank level in transition countries see, for example, Fries and Taci (2004).

${ }^{13}$ The ROA is an indicator of how profitable a company is relative to its total assets. It is calculated as the net income in relation to total assets of a bank. The ROE is the ratio of a corporation's net income relative to its equity.

${ }^{14}$ This notion is also supported in empirical studies. In a study that examines the cost efficiency of 289 banks in 15 east European countries, Fries and Taci (2004) find that privatised banks with a majority foreign ownership are more efficient than domestic-owned banks. In addition banking systems with a higher foreign penetration have lower costs. In a comparative analysis of the performance of foreignowned and domestic-owned banks operating in the Czech Republic and Poland, Weill (2003) also finds that on average foreign-owned banks are more efficient than domestic-owned banks.
} 
Table 2: Overhead costs of banks relative to total banking assets (in per cent)

\begin{tabular}{lcccccccccccccc}
\hline & \multicolumn{1}{c}{1994} & \multicolumn{1}{c}{1995} & \multicolumn{1}{c}{1996} & \multicolumn{1}{c}{1997} & \multicolumn{2}{c}{$\mathbf{1 9 9 8}$} & \multicolumn{2}{c}{$\mathbf{1 9 9 9}$} & \multicolumn{2}{c}{$\mathbf{2 0 0 0}$} \\
& FB & DB & FB & DB & FB & DB & FB & DB & FB & DB & FB & DB & FB & DB \\
\hline Czech Republic & 2.2 & 1.9 & 1.6 & 2.0 & 1.5 & 2.1 & 1.4 & 2.1 & 1.7 & 2.2 & 1.9 & 2.2 & 1.9 & 2.5 \\
Estonia & na & 6.0 & 3.0 & 5.0 & 3.0 & 4.0 & 2.0 & 3.0 & 3.0 & 1.0 & 3.0 & 0.0 & 3.0 & 0.0 \\
Hungary & 2.6 & 3.3 & 2.4 & 3.6 & 2.8 & 3.7 & 3.2 & 3.8 & 3.6 & 3.8 & 3.6 & 3.8 & 3.4 & 3.6 \\
Lithuania & na & na & 0.0 & 6.5 & 5.8 & 6.3 & 4.1 & 5.5 & 4.0 & 4.2 & 3.6 & 4.0 & 3.1 & 3.7 \\
Slovenia & 4.6 & 2.7 & 3.8 & 3.3 & 2.4 & 3.4 & 3.4 & 3.4 & 2.7 & 3.3 & 3.4 & 3.2 & 3.2 & 3.1 \\
\hline
\end{tabular}

Sources: National Central Banks (published as table 19c in ECB, 2004, p. 48).

Note: FB (foreign banks), DB (domestic banks).

Table 3: Return on assets of foreign and domestic banks (in per cent)

\begin{tabular}{|c|c|c|c|c|c|c|c|c|c|c|c|c|c|c|}
\hline & \multicolumn{2}{|c|}{1994} & \multicolumn{2}{|c|}{1995} & \multicolumn{2}{|c|}{1996} & \multicolumn{2}{|c|}{1997} & \multicolumn{2}{|c|}{1998} & \multicolumn{2}{|c|}{1999} & \multicolumn{2}{|c|}{2000} \\
\hline & FB & DB & FB & DB & FB & DB & FB & DB & FB & DB & FB & DB & FB & DB \\
\hline $\begin{array}{l}\text { Czech } \\
\text { Republic }\end{array}$ & 0.3 & 0.3 & 0.5 & -0.5 & 0.5 & 0.2 & 0.8 & -0.5 & 0.6 & -0.7 & 0.6 & -0.8 & 0.8 & 0.1 \\
\hline Estonia & na & 0.0 & -2.0 & 2.0 & -1.0 & 2.0 & 1.0 & 2.0 & -2.0 & -24.0 & 2.0 & -1.0 & 1.0 & 1.0 \\
\hline Hungary & 2.4 & 0.6 & 4.9 & 0.9 & 4.1 & 0.9 & 1.9 & 0.5 & 0.8 & -7.0 & 0.1 & 1.3 & 1.1 & 1.4 \\
\hline Lithuania & 0.0 & na & 0.0 & -2.9 & 2.9 & -2.4 & 1.5 & -2.3 & 1.5 & 0.4 & 2.1 & -1.0 & 1.2 & -0.4 \\
\hline Poland & na & na & 5.0 & na & 6.6 & na & na & na & na & na & na & na & na & na \\
\hline Slovenia & -0.8 & 0.5 & -0.1 & 1.1 & 0.5 & 1.1 & 0.9 & 1.1 & 0.7 & 1.2 & -0.1 & 0.8 & 0.1 & 1.3 \\
\hline
\end{tabular}

Table 4: Return on equity of foreign and domestic banks (in per cent)

\begin{tabular}{|c|c|c|c|c|c|c|c|c|c|c|c|c|c|c|}
\hline & \multicolumn{2}{|c|}{1994} & \multicolumn{2}{|c|}{1995} & \multicolumn{2}{|c|}{1996} & \multicolumn{2}{|c|}{1997} & \multicolumn{2}{|c|}{1998} & \multicolumn{2}{|c|}{1999} & \multicolumn{2}{|c|}{2000} \\
\hline & FB & DB & FB & DB & FB & DB & FB & DB & FB & DB & FB & DB & FB & DB \\
\hline $\begin{array}{l}\text { Czech } \\
\text { Republic }\end{array}$ & 4.2 & 2.9 & 8.5 & -6.5 & 9.4 & 3.1 & 13.3 & -7.3 & 9.1 & -11 & 7.9 & -14 & 10.6 & 1.9 \\
\hline Estonia & na & 5.0 & na & 19.0 & na & 23.0 & na & 23.0 & -10 & -21 & 14.0 & -9.0 & 9.0 & 9.0 \\
\hline Hungary & na & na & 44.6 & 12.4 & 31.3 & 20.8 & na & na & na & na & na & na & na & na \\
\hline Lithuania & na & na & 0.0 & -53 & 21.7 & -64 & 12.9 & -91 & 8.2 & 3.7 & 14.9 & -13 & 11.3 & -5.3 \\
\hline Poland & na & na & 315 & na & 51 & na & na & na & na & na & na & na & na & na \\
\hline Slovenia & 4.2 & 2.9 & 8.5 & -6.5 & 9.4 & 3.1 & 13.3 & -7.3 & 9.1 & -11 & 7.9 & -14 & 10.6 & 1.9 \\
\hline
\end{tabular}

Sources: National Central Banks (published as table 19b in ECB, 2004, p. 47)

An indicator of banks' allocative efficiency is the amount of non-performing loans (NPLs) in their balance sheets. Table 5 shows that, with the exception of Poland, Slovenia and Bulgaria, ${ }^{15}$ banks in the ACs have improved the quality of their loan portfolios markedly. The

${ }^{15}$ The high level of NPLs in Poland is related to the current legislation which makes it difficult for banks to write off bad loans. As a consequence they have to keep these loans on their books for a long time. The legislation is about to change. Similarly, the high level of bad loans in Bulgaria is due to a 
efforts of the Czech and Slovak Republic to tackle the problem of NPLs have already been mentioned. And while both countries still have a way to go until their banking sectors have cleaned up their loan portfolios, they have already managed to cut the amount of NPLs by almost two-thirds and three-quarters, respectively, between 1995 and 2002.

Table 5: Non-performing loans as a percentage of total loans

\begin{tabular}{|c|c|c|c|c|c|c|c|c|}
\hline & 1995 & 1996 & 1997 & 1998 & 1999 & 2000 & 2001 & 2002 \\
\hline Bulgaria & 12.5 & 15.2 & 13.0 & 11.8 & 17.5 & 10.9 & 7.9 & 10.4 \\
\hline $\begin{array}{l}\text { Czech } \\
\text { Republic }\end{array}$ & 26.6 & 21.8 & 19.9 & 20.3 & 21.5 & 19.3 & 13.7 & 9.4 \\
\hline Estonia & 2.5 & 2.0 & 2.1 & 4.0 & 2.9 & 1.3 & 1.2 & 0.8 \\
\hline Hungary & na & na & 6.6 & 7.9 & 4.4 & 3.1 & 2.9 & 4.6 \\
\hline Latvia & 19.0 & 20.0 & 10.0 & 6.8 & 6.8 & 5.0 & 3.1 & 2.1 \\
\hline Lithuania & 17.3 & 32.2 & 28.3 & 12.5 & 11.9 & 10.8 & 7.4 & 5.8 \\
\hline Poland & 23.9 & 14.7 & 11.5 & 11.8 & 14.5 & 16.8 & 20.1 & 24.6 \\
\hline Romania & 37.9 & 48.0 & 56.5 & 58.5 & 35.4 & 3.8 & 3.4 & 2.3 \\
\hline $\begin{array}{l}\text { Slovak } \\
\text { Republic }\end{array}$ & 41.3 & 31.8 & 33.4 & 44.3 & 32.9 & 26.2 & 24.3 & 11.2 \\
\hline Slovenia & 9.3 & 10.1 & 10.0 & 9.5 & 9.3 & 9.3 & 10.1 & na \\
\hline EU-15 & na & na & na & 4.7 & 4.5 & 4.2 & 4.0 & 3.9 \\
\hline
\end{tabular}

Sources: EBRD country database and ECB.

The efficiency indicators applied in this section show an overall trend of improving banking efficiency. This supports the notion that the proceeding transition process towards marketoriented economies and the process of European financial integration have benefited the development of the ACs' banking sectors.

Different measures of efficiency are also being used with respect to capital markets, such as stock market turnover as an indicator of market liquidity. Because capital markets are little used as a source of finance in the ACs, we will refrain from analysing these kinds of measures in this paper. The next section, however, takes a look at stock and bond market integration.

\section{$2.2 \quad$ STOCK AND BOND MARKET INTEGRATION}

Not only are the stock markets of the ACs very small in both relative and absolute size, they also show little correlation with the world and western European equity markets, as can be easily seen from figure 5. This is largely due to the low stock market turnover. We thus refrain from any quantitative analysis.

A more instructive approach relates to the strategies by which stock exchanges and policymakers in the ACs try to become competitive for a single European market for financial services (see also section 2.4). As noted before, only the stock markets of the Czech Republic, Hungary and Poland are somewhat relevant in an international context. The future of many stock exchanges in the ACs remains unclear, and might even be at stake as large corporations continue to seek foreign listing and as trading is diverted abroad (cf. Claessens et al., 2003). The ACs' stock exchanges are aware of these threats and try to respond in different ways, for example by strengthening their listing standards, trading systems and corporate governance standards. Another strategy is to create alliances with other stock exchanges in Europe. Following the examples of NOREX and Euronext, the Finnish HEX stock exchange group

more restrictive definition of NPLs. In general, definitions of NPLs vary across countries. Hence the figures presented here are not fully comparable. 
has acquired strategic ownership of the Tallinn Stock Exchange in Estonia in April 2001 and the Riga Stock Exchange in Latvia in August 2002, creating a common trading environment for Baltic securities. Another example of establishing alliances with stock exchanges in western Europe is the Warsaw Stock Exchange, which tried to build ties through (minority) shareholdings in EURONEXT Paris S.A. and Deutsche Börse AG.

\section{Figure 5: MSCI equity indices January 1997 - December 2003}

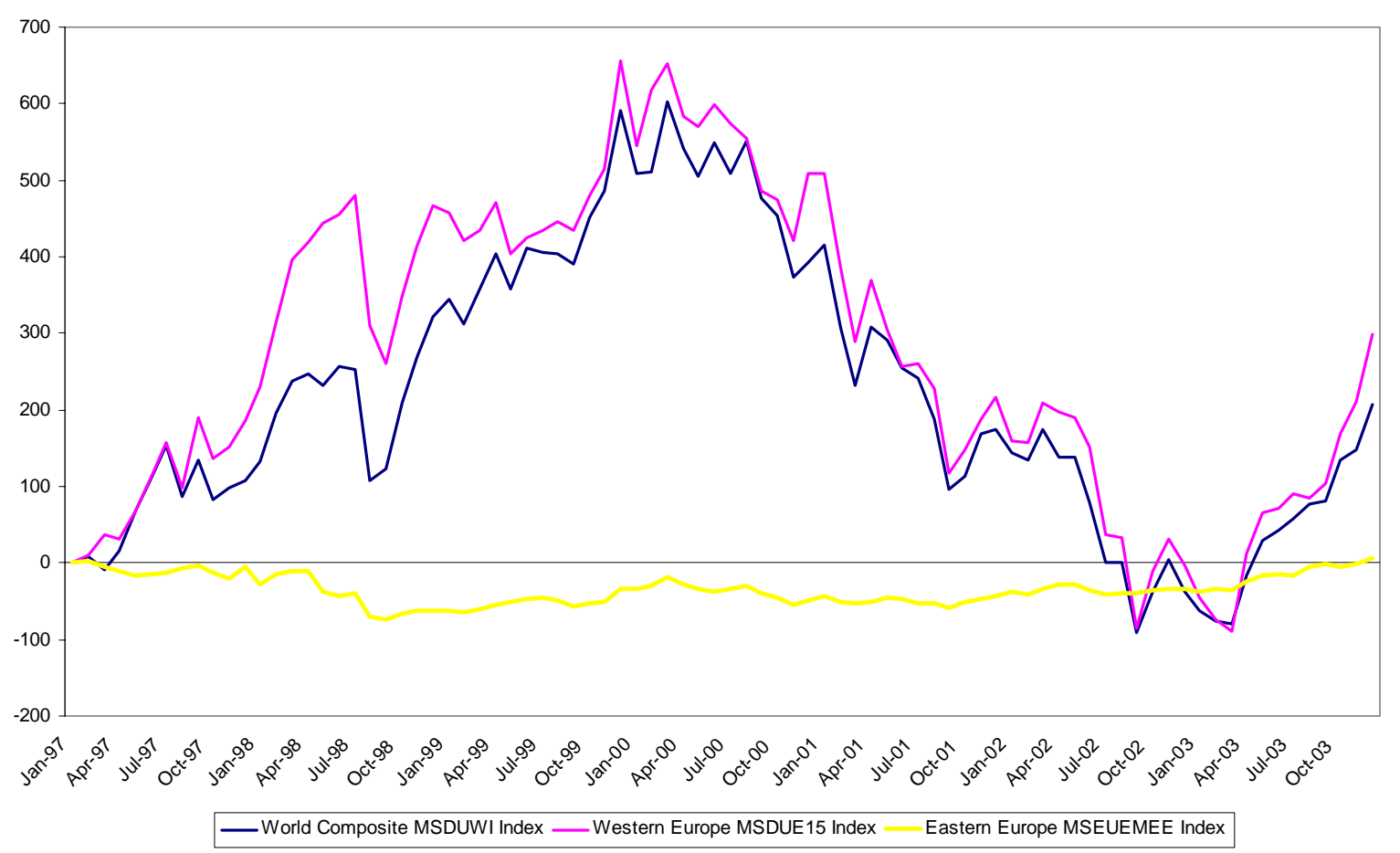

Source: Morgan Stanley Capital International (MSCl).

A trend for foreign listing is also observable in the bond markets. As domestic bond markets are largely underdeveloped in the ACs, both governments and large corporations frequently place bonds in international markets. The ACs' total international bond issues have reached the considerable volume of US\$ 5,619 million in 2002 (cf. figure 6). 
Figure 6: International bond issues by ACs (in US\$ million)

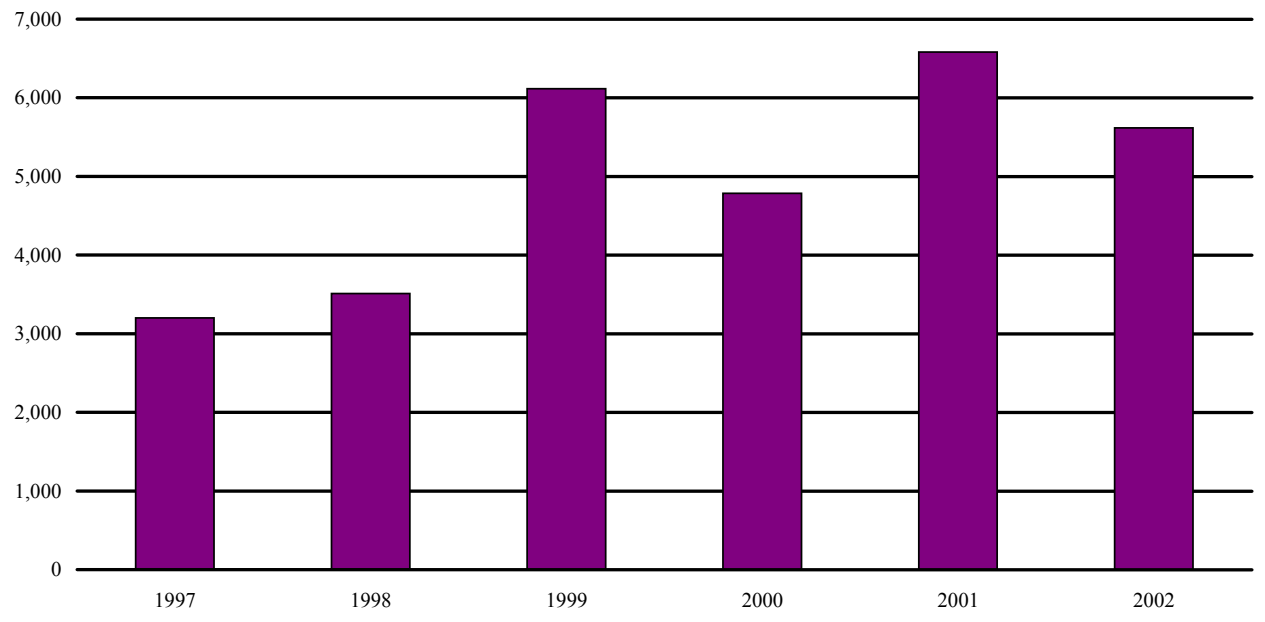

Source: Dealogic (Bondware).

\subsection{INTERBANK MARKET RATES AS AN INDICATOR FOR THE DEGREE OF CONVERGENCE IN THE MONEY MARKET}

The integration of markets entails an increase in transactions and a tendency for prices in those markets to converge. In terms of international financial integration this would imply an increase in capital flows and a tendency for prices and returns on traded financial assets in different countries to converge (De Brouwer, 1997). Full integration of money markets would imply that interbank market rates should converge. Figure 7 shows a general downward trend in the interbank market rates in the ACs, with rates moving closer to both Western European benchmarks, the LIBOR and EURIBOR.

Figure 7: 3 month interbank offer rates 1999-2003 (in per cent, monthly averages)

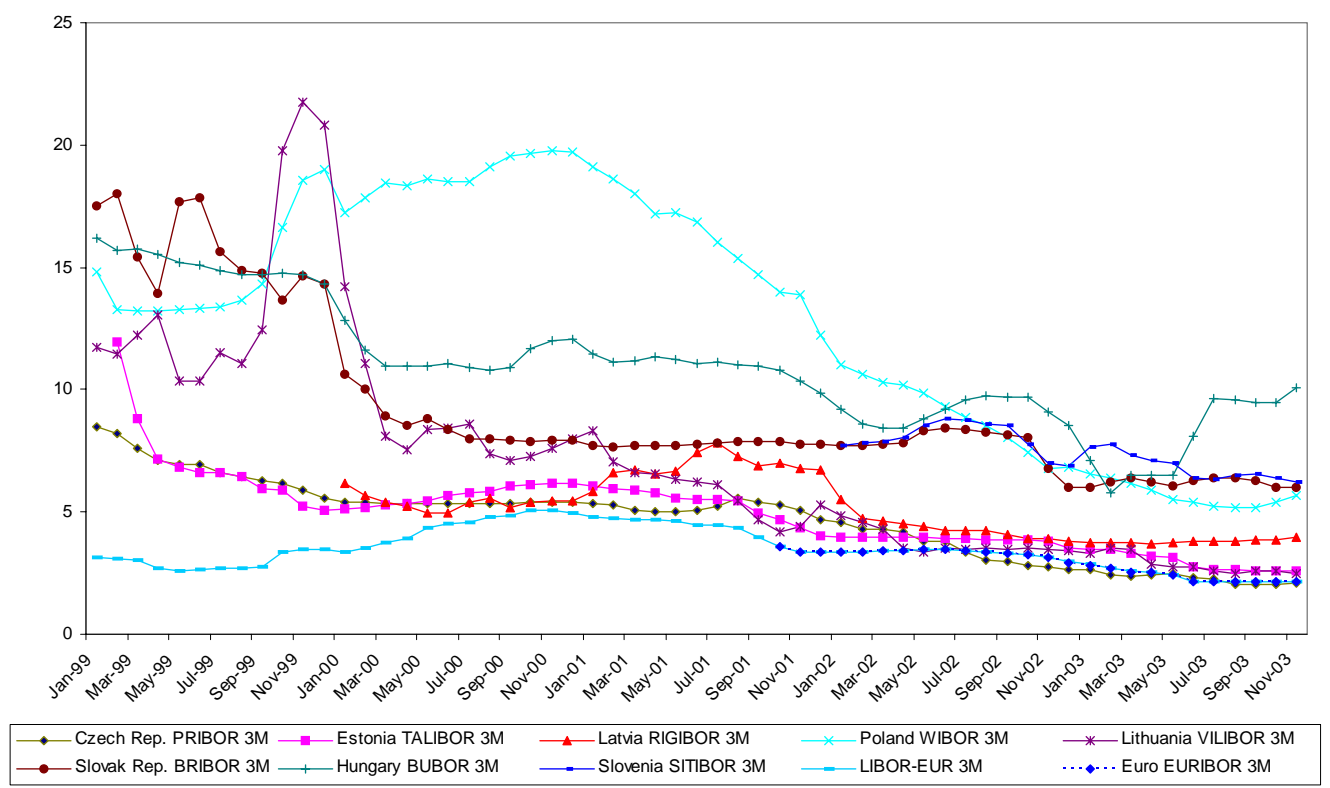

Sources: ISI Emerging Markets, the Central Banks of the Czech Republic, Estonia, Latvia, Lithuania, Hungary and the Bank Association of Slovenia. 
Table 6 shows the correlation between the interbank rates of the respective ACs with LIBOR for the whole period of 1999-2003. The correlation is relatively high for Latvia, Slovenia and Poland. The Czech Republic and Estonia show some correlation, while there is hardly any correlation for Hungary and Lithuania, and even a negative for the Slovak Republic.

Table 6: Correlation between 3 month interbank offer rates and LIBOR 1999-2003

\begin{tabular}{lcccccccc}
\hline & $\begin{array}{c}\text { Slovak } \\
\text { Republic } \\
\text { BRIBOR }\end{array}$ & Hungary & $\begin{array}{c}\text { Czech } \\
\text { Republic }\end{array}$ & $\begin{array}{c}\text { Latvia } \\
\text { BUBOR }\end{array}$ & Slovenia & Estonia & Lithuania & Poland \\
& PRIBOR & RIGIBOR & SITIBOR & TALIBOR & VILIBOR & WIBOR \\
\hline \hline $\begin{array}{l}\text { Years and } \\
\text { number of } \\
\text { observ- }\end{array}$ & $1999-$ & $1999-$ & $1999-$ & $2000-$ & $2002-$ & $1999-$ & $1999-$ & $1999-$ \\
ations & 2003 & 2003 & 2003 & 2003 & 2003 & 2003 & 2003 & 2003 \\
Correlation & 1,137 & 1,139 & 1,150 & 896 & 402 & 1,132 & 1,143 & 1,144 \\
\hline
\end{tabular}

Source: Author's calculations.

Table 7 shows the same correlations, but separately for the years 1999, 2000, 2001, 2002 and 2003. Integration would imply increasing correlations between the respective interbank rates and the LIBOR, as is the case with the Czech Republic, Estonia, Poland and Slovenia.

Table 7: Annual correlation between 3-month interbank offer rates and LIBOR 19992003

\begin{tabular}{|c|c|c|c|c|c|c|c|c|}
\hline & $\begin{array}{c}\text { Slovak } \\
\text { Republic } \\
\text { BRIBOR }\end{array}$ & $\begin{array}{c}\text { Hungary } \\
\text { BUBOR }\end{array}$ & $\begin{array}{l}\text { Czech } \\
\text { Republic } \\
\text { PRIBOR }\end{array}$ & $\begin{array}{c}\text { Latvia } \\
\text { RIGIBOR }\end{array}$ & $\begin{array}{l}\text { Slovenia } \\
\text { SITIBOR }\end{array}$ & $\begin{array}{l}\text { Estonia } \\
\text { TALIBOR }\end{array}$ & $\begin{array}{c}\text { Lithuania } \\
\text { VILIBOR }\end{array}$ & $\begin{array}{l}\text { Poland } \\
\text { WIBOR }\end{array}$ \\
\hline 1999 & -0.26 & -0.12 & -0.20 & na & na & -0.16 & 0.85 & 0.82 \\
\hline 2000 & -0.84 & -0.17 & 0.00 & -0.40 & na & 0.96 & -0.71 & 0.90 \\
\hline 2001 & -0.53 & 0.87 & 0.27 & -0.13 & na & 0.98 & 0.77 & 0.92 \\
\hline 2002 & 0.87 & 0.08 & 0.61 & 0.35 & 0.79 & 0.85 & 0.09 & 0.69 \\
\hline 2003 & -0.15 & -0.81 & 0.89 & -0.53 & 0.93 & 0.96 & 0.86 & 0.93 \\
\hline
\end{tabular}

Source: Author's calculations.

\subsection{INDICATORS OF INSTITUTIONAL DIFFERENCES THAT MAY INDUCE FINANCIAL MARKET SEGMENTATION}

By hindering the free movement of financial institutions and services, legal and institutional barriers can seriously hamper the process of financial integration. ${ }^{16}$ To eliminate such barriers and to fully exploit the benefits of economic integration in a borderless market with unrestricted movement of people, goods and services (as envisaged through the Single Market Act of 1985), the European Community launched the Single Market programme for financial services. The aim of the Single Market framework was to create a level playing field for all financial institutions in the common market, and to enable firms as well as individuals to take advantage of deeper and more liquid financial markets with a wider range of financial instruments and services. The integration process was based on four principles: the

\footnotetext{
${ }^{16}$ Other efficiency barriers to operating across borders might include distance, differences in language, culture, currency, and explicit or implicit rules against foreign competitors (cf. Berger, De Young and Udell, 2001).
} 
harmonisation of standards, home country control and supervision, the provision of a single European passport for financial institutions, and mutual recognition (Reszat, 2003, p. 20). ${ }^{17}$

The Financial Services Action Plan (FSAP), adopted by the European Commission in May 1999, outlines a series of policy objectives and specific measures to improve the Single Market for financial services. The FSAP aims to tackle three strategic goals, namely completing a single wholesale market for financial services, developing open and secure markets for retail financial services and ensuring the continued stability of EU financial markets through state-of-the-art prudential rules and supervision.

Before accession, all ACs had to adopt the whole acquis communautaire, the common legal framework of the EU. The acquis includes the Maastricht Treaty, as well as a variety of further, detailed regulations (see Lanoo and Stirböck, 2000, pp. 286-8). In its assessments before accession, the European Commission has approved that all ACs (Bulgaria and Romania excluded) have aligned their regulatory frameworks with EU legislation to a sufficient extent that enables them to join the EU. Nevertheless, the ACs still need to work towards an effective implementation and enforcement of the acquis. Furthermore, a number of transitional arrangements and exemptions were concluded during accession negotiations (ECB, 2004, p. 53). But while the regulatory and supervisory framework still need to be polished, and issues such as law enforcement and accounting standards need to be strengthened, a great degree of harmonisation has already been achieved (Racocha, 2003, p. $10) .^{18}$

Tables 8 and 9 show that, according to the EBRD's transition indicators for the progress made in banking reform and securities markets, the present stage of the regulatory framework is largely satisfactory. The measurement scales for the indicators range from 1 to $4+$, where 1 represents little or no change from a rigid centrally planned economy and a 4+ represents the standards of an industrialised market economy (with 0.3 decimal points added or subtracted for + and - ratings). ${ }^{19}$

\footnotetext{
${ }^{17}$ For a discussion of the institutional and regulatory framework of the European capital markets and the quest for a harmonisation of standards and regulations see Gros and Lannoo (2000).

${ }^{18}$ As mentioned before, the EU-15 standards constitute a kind of moving target, and this is particularly true for the regulatory and supervisory framework which is currently under review under the FSAP and the Lamfalussy framework. Having just adjusted more or less to the current EU framework for financial services, further challenges lie ahead.

${ }^{19}$ The classification system for the banking reform and interest rate liberalisation indicator is as follows: 1) Little progress beyond establishment of a two-tier-system. 2) Significant liberalisation of interest rates and credit allocation; limited use of directed credit or interest rate ceilings. 3) Substantial progress in establishing bank solvency and of a framework for prudential supervision and regulation; full interest rate liberalisation with little preferential access to cheap refinancing; significant lending to private enterprises and significant presence of private banks. 4) Significant movement of banking laws and regulation towards BIS standards; well-functioning banking competition and effective prudential supervision; significant term lending to private enterprises; substantial financial deepening. 4+) Standards and performance norms of advanced industrial economies: full convergence of banking laws and regulations with BIS standards; provision of full set of competitive banking services. The classification system for the securities markets and non-bank financial institutions indicator is: 1) Little progress. 2) Formation of securities exchanges, market-makers and brokers; some trading in government paper and/or securities; rudimentary legal and regulatory framework for the issuance and trading of securities. 3) Substantial issuance of securities by private enterprises; establishment of independent share registries, secure clearance and settlement procedures, and some protection of minority shareholders; emergence of non-bank financial institutions (e.g. investment funds, private insurance and pension funds, leasing companies) and associated regulatory framework. 4) Securities laws and regulations approaching IOSCO standards; substantial market liquidity and capitalisation; well-functioning non-bank financial institutions and effective regulation. 4+) Standards and
} 
Table 8: Progress in banking reform and interest rate liberalisation

\begin{tabular}{lcccccc}
\hline & $\mathbf{1 9 9 8}$ & $\mathbf{1 9 9 9}$ & $\mathbf{2 0 0 0}$ & $\mathbf{2 0 0 1}$ & $\mathbf{2 0 0 2}$ & $\mathbf{2 0 0 3}$ \\
\hline \hline Bulgaria & 2.7 & 2.7 & 3.0 & 3.0 & 3.3 & 3.3 \\
Czech Republic & 3.0 & 3.3 & 3.3 & 3.7 & 3.7 & 3.7 \\
Estonia & 3.3 & 3.7 & 3.7 & 3.7 & 3.7 & 3.7 \\
Hungary & 4.0 & 4.0 & 4.0 & 4.0 & 4.0 & 4.0 \\
Latvia & 2.7 & 3.0 & 3.0 & 3.3 & 3.7 & 3.7 \\
Lithuania & 3.0 & 3.0 & 3.0 & 3.0 & 3.0 & 3.0 \\
Poland & 3.3 & 3.3 & 3.3 & 3.3 & 3.3 & 3.3 \\
Romania & 2.3 & 2.7 & 2.7 & 2.7 & 2.7 & 2.7 \\
Slovak Republic & 2.7 & 2.7 & 3.0 & 3.3 & 3.3 & 3.3 \\
Slovenia & 3.0 & 3.3 & 3.3 & 3.3 & 3.3 & 3.3 \\
\hline
\end{tabular}

Source: EBRD Transition Report 2003.

Table 9: Progress in reform of securities markets and non-bank financial institutions

\begin{tabular}{lcccccc}
\hline & $\mathbf{1 9 9 8}$ & $\mathbf{1 9 9 9}$ & $\mathbf{2 0 0 0}$ & $\mathbf{2 0 0 1}$ & $\mathbf{2 0 0 2}$ & $\mathbf{2 0 0 3}$ \\
\hline \hline Bulgaria & 2.0 & 2.0 & 2.0 & 2.0 & 2.3 & 2.3 \\
Czech Republic & 3.0 & 3.0 & 3.0 & 3.0 & 3.0 & 3.0 \\
Estonia & 3.0 & 3.0 & 3.0 & 3.0 & 3.3 & 3.3 \\
Hungary & 3.3 & 3.3 & 3.7 & 3.7 & 3.7 & 3.7 \\
Latvia & 2.3 & 2.3 & 2.3 & 2.3 & 3.0 & 3.0 \\
Lithuania & 2.3 & 2.7 & 3.0 & 3.0 & 3.0 & 3.0 \\
Poland & 3.3 & 3.3 & 3.7 & 3.7 & 3.7 & 3.7 \\
Romania & 2.0 & 2.0 & 2.0 & 2.0 & 2.0 & 2.0 \\
Slovak Republic & 2.3 & 2.3 & 2.3 & 2.3 & 2.3 & 2.7 \\
Slovenia & 2.7 & 2.7 & 2.7 & 2.7 & 2.7 & 2.7 \\
\hline
\end{tabular}

Source: EBRD Transition Report 2003.

\subsection{THE ROLE OF FOREIGN BANKS}

The measures used so far were only partly able to display the degree of financial integration attained hitherto. This section will look at one of the most striking features of the ACs' financial systems, namely the penetration of the ACs' banking sectors by foreign, and particularly western European, banks.

A distinction can be made between two aspects of foreign banking activity: cross-border activities from the home country where the bank is headquartered and activities of local bank subsidiaries and branches in the host country.

Annex 1.1 shows the foreign claims of BIS reporting banks on individual countries by nationality of reporting banks for end-September $2003 .^{20}$ Foreign claims refer to claims on

performance norms of advanced industrial economies: full convergence of securities laws and regulations with IOSCO standards; fully developed non-bank intermediation (EBRD, 2003, p. 17).

${ }^{20}$ Commercial banks and other deposit-taking institutions in 27 jurisdictions report to the BIS consolidated banking statistics, which are estimated to cover more than 95 per cent of international 
borrowers resident outside the country in which the bank is headquartered. Foreign claims can be disaggregated into cross-border claims and local claims booked by foreign offices. The latter refer to claims on residents of the country in which the foreign office is located. For example, claims on Czech residents booked by an Austrian bank's Czech-located subsidiary would be reported by Austria as local claims on the Czech Republic. Unfortunately, the BIS consolidated banking statistics do not publish breakdown data on cross-border and local claims so that data on cross-border lending to the ACs are not easily available. ${ }^{21}$ The data presented in annexes 1.1-1.4 nevertheless are a good indicator for the importance of foreign bank penetration throughout the ACs and clearly show the importance of both cross-border finance and financing through local subsidiaries for the ACs.

Annex 1.2 shows that, from the point of view of most BIS reporting countries, lending to the ACs constitutes only a very small fraction of their international exposure. For all EU-13 countries, ${ }^{22}$ western Europe is the most important market for international banking services, with more than half of international lending being directed to the EU-15 countries. On average, only 2.3 per cent of the EU-13 countries' foreign lending is directed towards the ACs. Foreign claims to the ACs have only reached a considerable size in relation to total international lending for Austria (15.3 per cent), and, to a lesser extent, for Italy (9.2 per cent), Sweden (6.7 per cent), Belgium (6.5 per cent) and Finland (5.0 per cent). In Germany - the single most important lender to the ACs with a total lending volume of US\$ 66 billion (cf. annex 1.1) - lending to the ACs amounts to only 2.7 per cent of its total international lending.

But the opposite is true for the ACs. Foreign lending from western Europe is of utmost importance, both in absolute and relative terms. About 86 per cent of the ACs' total foreign claims come from banks headquartered in the EU-13 (cf. annex 1.1). In the Czech Republic, the Slovak Republic and the Baltic states even more than 90 per cent of foreign claims stem from EU-13 banks. Annex 1.3 shows that total foreign claims vis-à-vis the ACs equal nearly 100 per cent of their domestic credit. This ratio is only 56 per cent for the western European countries, that is foreign bank penetration in the ACs is almost double compared with the old EU member countries. On average, foreign claims from EU-13 banks are 85 per cent relative to domestic credit. Total foreign claims and foreign claims from EU-13 banks respectively (both relative to domestic credit) are particularly high for Estonia (141.8 per cent / 138.7 per cent), the Czech Republic (121.8 per cent / 111.0 per cent), Lithuania (121.4 per cent / 115.2 per cent) and Poland (116.6 per cent / 92.9 per cent). Because of the small size of the ACs' banking systems, these numbers are considerably lower in relation to GDP (see annex 1.4).

To get a more complete picture, it would be sensible to also take a look at the reverse flow of capital (Buch et al. 2003, p. 59). Unfortunately the BIS does not provide such data on the ACs' foreign assets. However, the IFS data on aggregate external assets (which has also been used to calculate the IFIGDP ${ }_{\text {it }}$ indicator in section two) indicate that the ACs indeed hold

banking business. For details on the compilation of the BIS Consolidated Banking Statistics see BIS (2003).

${ }^{21}$ Foreign claims can also be disaggregated into international claims and local claims denominated in local currency, and the BIS does publish these data. However, regrettably, data for this breakdown is incomplete for some reporting countries, including Denmark, Germany and Ireland. As particularly German banks' exposure in the region is very high, these data give an incomplete picture. To obtain the "true" amount of cross-border credit, De Haas and Van Lelyveld (2004) use a combination of BIS and BankScope data. Following their methodology would, however, involve great efforts and would stand in no relation to the insights it would offer for this piece of work. We shall hence present just the plain BIS data on foreign claims.

${ }^{22}$ EU-13 comprises the EU-15 countries minus Greece and Luxembourg, whose banks are not listed in the BIS Consolidated Banking Statistics. 
quite large foreign assets, a large share of which can be expected to be invested in western Europe.

The importance of foreign banks for the ACs' banking systems can be illustrated even more by looking at the actual presence of foreign banks in the host country in the form of subsidiaries. The ACs' banking sectors generally consist of previously state-owned banks, new banks established after 1990 as private institutions, and subsidiaries and branches of foreign banks. While the approaches to bank privatisation differed across the ACs, the results are now rather comparable (Racocha, 2003, p. 5). With the exception of Slovenia, and to a lesser extent Poland, Latvia and Hungary, ${ }^{23}$ the banking sectors are largely dominated by foreign-owned institutions, ${ }^{24}$ most of which are from the "old" EU. State ownership only has a significant portion in Slovenia (40.7 per cent), Poland (25.3 per cent) and Lithuania (12 per cent) (cf. Figure 8).

\section{Figure 8: Bank ownership, 2002}

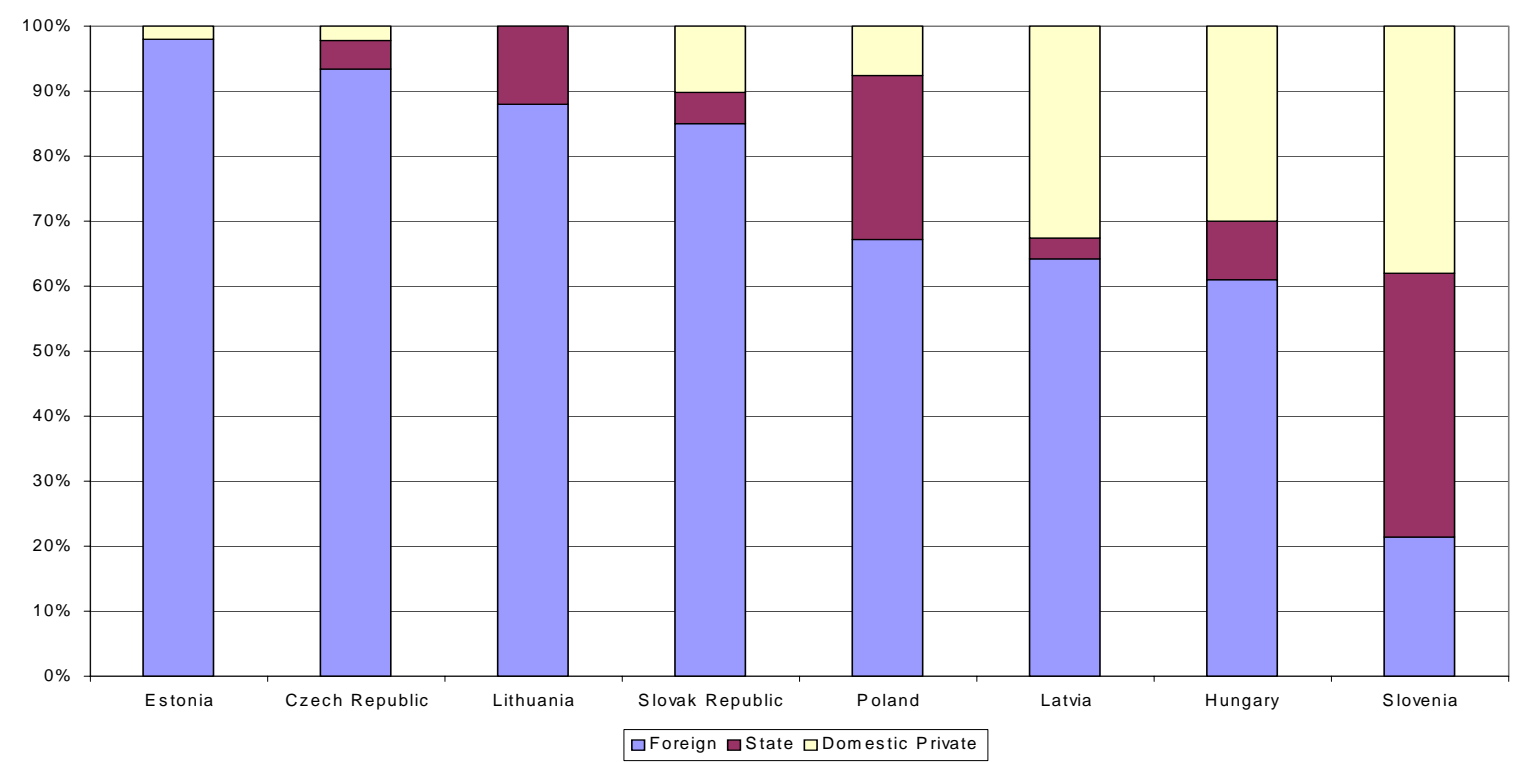

Source: Czech National Bank / Racocha (2003, p. 5).

Table 10 shows that the assets held by foreign-owned banks, relative to the assets of all banks, have increased significantly over the past decade, from an (unweighted) average of 22 per cent in 1996 to 71 per cent in 2002. Only Slovenia still shows a fairly low level with 17 per cent, the result of a cautious government attitude towards the involvement of foreign banks.

\footnotetext{
${ }^{23}$ The sale of Postabank to Erste Bank of Austria in 2003 has significantly boosted the share of foreign ownership in Hungary.

${ }^{24}$ Banks are classified as foreign-owned if foreign ownership exceeds 50 per cent.
} 
Table 10: Assets of foreign-owned banks relative to assets of all banks

\begin{tabular}{lcccccccccc}
\hline & $\mathbf{1 9 9 3}$ & $\mathbf{1 9 9 4}$ & $\mathbf{1 9 9 5}$ & $\mathbf{1 9 9 6}$ & $\mathbf{1 9 9 7}$ & $\mathbf{1 9 9 8}$ & $\mathbf{1 9 9 9}$ & $\mathbf{2 0 0 0}$ & $\mathbf{2 0 0 1}$ & $\mathbf{2 0 0 2}$ \\
\hline \hline Bulgaria & na & na & na & na & na & 0.32 & 0.43 & 0.75 & 0.73 & 0.75 \\
Czech Republic & 0.05 & 0.11 & 0.16 & 0.20 & 0.24 & 0.26 & 0.39 & 0.66 & 0.90 & 0.86 \\
Estonia & 0.00 & 0.00 & 0.02 & 0.02 & 0.29 & 0.90 & 0.90 & 0.97 & 0.98 & 0.98 \\
Hungary & 0.09 & 0.13 & 0.37 & 0.43 & 0.61 & 0.59 & 0.61 & 0.67 & 0.65 & 0.84 \\
Latvia & na & na & 0.35 & 0.51 & 0.71 & 0.79 & 0.74 & 0.74 & 0.65 & 0.43 \\
Lithuania & 0.00 & 0.00 & 0.00 & 0.28 & 0.41 & 0.51 & 0.37 & 0.55 & 0.78 & 0.96 \\
Poland & 0.03 & 0.03 & 0.04 & 0.14 & 0.16 & 0.17 & 0.49 & 0.73 & 0.72 & 0.71 \\
Romania & na & na & na & na & 0.11 & 0.15 & 0.44 & 0.47 & 0.51 & 0.53 \\
Slovak Republic & na & na & na & 0.13 & 0.19 & 0.24 & 0.24 & 0.43 & 0.78 & 0.86 \\
Slovenia & na & 0.04 & 0.05 & 0.05 & 0.05 & 0.05 & 0.05 & 0.15 & 0.15 & 0.17 \\
\hline
\end{tabular}

Source: EBRD country database.

As a further illustration, annex 2 lists the 20 largest banks in the ACs, of which the vast majority is owned by foreign banks.

All in all, it is apparent that the ACs have become integrated into international, and especially European, capital markets at an impressive speed over the past decade. Market shares of foreign banks are much higher than in the average western European country and the ACs today rely to a substantial degree on international bank lending. ${ }^{25}$

${ }^{25}$ See also Buch et al. (2003) and De Haas and Van Lelyveld (2004). 


\section{CONSEQUENCES OF FINANCIAL INTEGRATION AND INCREASED FINANCIAL MARKET COMPETITION FOR SME FINANCE IN THE NEW EU MEMBER STATES}

The previous section has shown that the ACs' financial sectors are already highly integrated with the Western European and international financial markets, particularly through the strong presence of foreign banks. This section now turns to potential implications of European financial integration for the ACs. Firstly, it will look at the financing conditions of businesses in the ACs, using firm level data on the business environment. It then goes on to discuss potential effects of the concentration of financial services and the dominance of foreignowned financial institutions for the provision of financial services to small and medium-sized enterprises (SMEs) in the ACs.

\subsection{FINANCING CONDITIONS IN THE ACs}

This section uses data from the 2002 Business Environment and Enterprise Performance Survey (BEEPS) which was implemented jointly by the EBRD and the World Bank. The BEEPS aims to investigate the extent to which government policies and practices facilitate or impede business activity and investment in central and eastern Europe and the Commonwealth of Independent States. It also includes unique information on the access to finance and the financing conditions for firms in the region. The 2002 BEEPS covers 6,153 firms in 26 transition countries and includes data on 2,427 firms from the ten ACs. ${ }^{26}$

The results given in Table 11 indicate that, with the exception of Poland, the financing conditions for businesses have improved in the ACs since the first survey in 1999. This is what would have been hoped for, as integration should theoretically bring about an improvement in the less developed region (as discussed in section one).

Table 11: Average score for the financing of business, 1999 and 2002

\begin{tabular}{ccccccccccc}
\hline & Bulgaria & $\begin{array}{c}\text { Czech } \\
\text { Republic }\end{array}$ & Estonia & Hungary & Latvia & Lithuania & Poland & Romania & $\begin{array}{c}\text { Slovak } \\
\text { Republic }\end{array}$ & Slovenia \\
\hline \hline 1999 & 3.05 & 2.88 & 2.84 & 2.86 & 2.84 & 3.24 & 2.86 & 3.71 & 3.37 & 2.73 \\
2002 & 2.83 & 2.49 & 1.99 & 2.26 & 1.91 & 1.81 & 2.91 & 2.67 & 2.53 & 2.00 \\
\hline
\end{tabular}

Source: Author's calculations with BEEPS 1999 and 2002 datasets.

Note: The average score is based on a scale of 1 (best case) to 4 (worst case).

In the following, the results of the BEEPS 2002 are looked at more closely to see whether the survey indicates differences in the financing conditions of SMEs and large firms, and between rural and urban firms. It is important to note that for the BEEPS, firms were asked to appraise the conditions of their business environment, and that these evaluations are subjective by nature. Hence the judgments of firms of different size, location and nationality cannot be compared at face value. Nevertheless, the BEEPS gives a best possible picture of the sentiment in the region.

\footnotetext{
${ }^{26}$ For details on BEEPS see chapter two of EBRD (2002) and Fries et al. (2003). Annex 3 gives an overview of the dataset, including the total number of observations per country, the number of small, medium and large firms as well as rural and urban firms.
} 
Table 12 gives the average score for all 2,427 firms that were questioned in the ACs with respect to access to financing (e.g. collateral required) and to the cost of financing (e.g. interest rates and charges) on a score from 1 (no obstacle) to 4 (major obstacle). ${ }^{27}$ Distinction with respect to geographical location does not give any clear pattern for either "access to finance" or "cost of finance". Looking at the size of firms, however, shows that small firms (with less than 50 employees) on average find it harder to obtain financing than large firms (250-9,999 employees). ${ }^{28}$ The same seems to be true for the cost of financing: on average, smaller firms perceive the cost of financing as a greater obstacle for the operation and growth of their businesses than do large firms.

Table 12: Access to and cost of finance, average score for all ACs

\begin{tabular}{lcc}
\hline & Access to finance & Cost of finance \\
\hline \hline For all firms & 2.32 & 2.56 \\
By geographical location (city or town) & & \\
(1) Capital & 2.21 & 2.31 \\
(2) Other, over 1 million inhabitants & 2.75 & 3.5 \\
(3) Other, 250,000-1,000,000 & 2.58 & 2.96 \\
(4) Other, 50,000-250,000 & 2.26 & 2.5 \\
(1-4) 50,000 and above (urban) & 2.32 & 2.56 \\
(5) Under 50,000 (rural) & 2.34 & 2.63 \\
By size of firm & & \\
Small (2-49 employees) & 2.41 & 2.63 \\
Medium (50-249 employees) & 2.21 & 2.49 \\
Large (250-9,999 employees) & 2.07 & 2.36 \\
\hline
\end{tabular}

Source: Author's calculations with BEEPS 2002 dataset.

Note: The average score is based on a scale of 1 (no obstacle) to 4 (major obstacle).

Annex 4 presents the results by country. For the Czech Republic, Estonia, Hungary, and the Slovak Republic a very clear pattern for both access to and costs of bank financing emerges. In general, small firms seem to have greater problems in obtaining finance than medium-sized firms, which lag behind large firms. The evidence is somewhat mixed for the other countries, as medium-sized firms sometimes give worse rankings than small firms. Nevertheless, with the exception of Latvia, in all countries small firms on average face bigger obstacles in financing their businesses than larger firms.

This pattern is confirmed by the results presented in table 13. Firms were asked how easy it would be for them to obtain a short-term working capital loan on commercial terms, and how easy it would be for them to obtain a longer term banking loan for new investment. As before, there is not a strong geographical pattern, ${ }^{29}$ but small firms again seem to have most problems in accessing both short-term and long-term finance. While small firms on average describe their prospects to obtain short-term finance as "fairly difficult", large firms tend to judge it as "fairly easy", with medium-sized firms in between. The results by country are presented in annex 5 .

\footnotetext{
${ }^{27}$ The exact question in BEEPS 2002 was: "How problematic are these different factors for the operation and growth of your business?"

${ }^{28}$ Firms with less than two or more than 10,000 employees were excluded from the BEEPS.

${ }^{29}$ The results by country (annex 5) show that in Bulgaria, the Czech Republic, Estonia and Lithuania urban firms on average experience less difficulty in accessing short and long-term capital from commercial banks than rural firms. The same is true for short-term finance in Hungary and Latvia, and for long-term finance in Romania and Slovenia. The differences, however, are rather marginal.
} 
Table 13: Access to short-term and long-term capital, average score for all ACs

\begin{tabular}{lcc}
\hline & $\begin{array}{c}\text { Access to short-term } \\
\text { finance }\end{array}$ & $\begin{array}{c}\text { Access to long-term } \\
\text { finance }\end{array}$ \\
\hline \hline For all firms & 3.32 & 3.06 \\
$\begin{array}{l}\text { By geographical location } \\
\text { (city or town) }\end{array}$ & & \\
(1) Capital & 3.42 & 3.09 \\
(2) Other, over 1 million inhabitants & 3.75 & 3.75 \\
(3) Other, 250,000-1,000,000 & 3.16 & 2.91 \\
(4) Other, 50,000-250,000 & 3.35 & 3.14 \\
(1-4) 50,000 and above (urban) & 3.34 & 3.07 \\
(5) Under 50,000 (rural) & 3.27 & 3.05 \\
By size of firm & & \\
Small (2-49 employees) & 3.16 & 2.91 \\
Medium (50-249 employees) & 3.54 & 3.24 \\
Large (250-9,999 employees) & 3.78 & 3.49 \\
\hline
\end{tabular}

Source: Author's calculations with BEEPS 2002 dataset.

Note: The average score is based on a scale from 1 (impossible), 2 (very difficult), 3 (fairly difficult), 4 (fairly easy) to 5 (very easy).

The picture becomes more complete when the sources of finance are reviewed. Table 14 shows that the proportion of external finance as part of the total financing is rather small, and that borrowing from banks in general is very low. Only 9.59 per cent of working capital is financed by local private commercial banks, state-owned banks and foreign banks, and only 9.98 per cent of long-term financing comes from these banks. This reflects the low level of financial deepening in the ACs, which is also apparent in their low bank lending to GDP ratios discussed before (cf. section two).

Table 14: Sources of finance for working capital and new investment, average for all ACs (in per cent)

\begin{tabular}{lcc}
\hline Source of finance & Working capital & New investments \\
\hline \hline Internal funds/retained earnings & 64.79 & 48.83 \\
Equity (i.e. issue of new shares) & 5.12 & 3.41 \\
Borrowing from local private commercial banks & 5.48 & 5.40 \\
Borrowing from state-owned banks, including state & 3.14 & 3.35 \\
development banks & 0.97 & 1.24 \\
Borrowing from foreign banks & 3.15 & 2.33 \\
Loans from family/friends & 0.90 & 0.65 \\
Money lenders or other informal sources (other & 5.63 & 1.33 \\
than family/friends) & 1.45 & 0.36 \\
Trade credit from suppliers & 0.52 & 0.37 \\
Trade credit from customers & 2.20 & 5.69 \\
Credit cards & 1.81 & 1.70 \\
Leasing arrangement & 2.33 & 2.11 \\
Government (other than state-owned banks) & 97.49 & 76.77 \\
Other & & \\
Sum &
\end{tabular}

Source: Author's calculations with BEEPS 2002 dataset.

Tables 14 and 15 show that roughly half or more of the financing of working capital and of new investments of the interviewed firms is generated by internal funds. In their financing of working capital small firms rely to almost 70 per cent on internal funds, much more than large 
and medium-sized firms. Financing through equity generally plays a minor role, which reflects the low market capitalisation in the ACs. Equity financing only plays a considerable role in Hungary and Latvia, and interestingly also for small firms in the Czech and Slovak Republic (see annex 6 for the results by country). Trade credit from suppliers is a relatively important source of finance for large and medium-sized firms in Bulgaria, Latvia, Lithuania and Poland, and for small firms in Latvia. Government finance appears to be of importance for larger firms in Bulgaria and medium-sized firms in the Czech and Slovak Republic.

Table 15: Sources of finance for all ACs, by size of firm (in per cent)

\begin{tabular}{|c|c|c|c|c|c|c|}
\hline & \multicolumn{2}{|c|}{ Large firms } & \multicolumn{2}{|c|}{ Medium firms } & \multicolumn{2}{|c|}{ Small firms } \\
\hline & $\begin{array}{l}\text { Working } \\
\text { capital } \\
\end{array}$ & $\begin{array}{c}\text { New } \\
\text { investment }\end{array}$ & $\begin{array}{l}\text { Working } \\
\text { capital }\end{array}$ & $\begin{array}{c}\text { New } \\
\text { investment }\end{array}$ & $\begin{array}{l}\text { Working } \\
\text { capital }\end{array}$ & $\begin{array}{c}\text { New } \\
\text { investment }\end{array}$ \\
\hline $\begin{array}{l}\text { Internal funds/retained } \\
\text { earnings }\end{array}$ & 56.25 & 48.08 & 59.73 & 49.47 & 67.99 & 48.82 \\
\hline $\begin{array}{l}\text { Equity (i.e. issue of new } \\
\text { shares) }\end{array}$ & 3.75 & 1.82 & 5.09 & 3.31 & 5.40 & 3.77 \\
\hline $\begin{array}{l}\text { Borrowing from local } \\
\text { private commercial } \\
\text { banks }\end{array}$ & 9.66 & 9.89 & 8.73 & 8.42 & 3.71 & 3.65 \\
\hline $\begin{array}{l}\text { Borrowing from state- } \\
\text { owned banks, including } \\
\text { state development } \\
\text { banks }\end{array}$ & 4.87 & 4.16 & 3.22 & 2.64 & 2.75 & 3.37 \\
\hline $\begin{array}{l}\text { Borrowing from foreign } \\
\text { banks }\end{array}$ & 2.55 & 3.48 & 1.45 & 1.89 & 0.50 & 0.59 \\
\hline $\begin{array}{l}\text { Loans from } \\
\text { family/friends }\end{array}$ & 0.65 & 0.47 & 0.58 & 0.78 & 4.35 & 3.14 \\
\hline $\begin{array}{l}\text { Money lenders or other } \\
\text { informal sources (other } \\
\text { than family/friends) }\end{array}$ & 0.26 & 0.32 & 0.77 & 0.47 & 1.07 & 0.77 \\
\hline $\begin{array}{l}\text { Trade credit from } \\
\text { suppliers }\end{array}$ & 7.20 & 1.82 & 6.75 & 1.40 & 5.01 & 1.20 \\
\hline $\begin{array}{l}\text { Trade credit from } \\
\text { customers }\end{array}$ & 1.77 & 1.03 & 1.40 & 0.28 & 1.42 & 0.24 \\
\hline Credit cards & 0.36 & 0.12 & 0.10 & 0.02 & 0.67 & 0.51 \\
\hline Leasing arrangement & 2.05 & 5.84 & 1.89 & 4.85 & 2.31 & 5.88 \\
\hline $\begin{array}{l}\text { Government (other than } \\
\text { state-owned banks) }\end{array}$ & 2.17 & 2.20 & 3.78 & 3.88 & 1.19 & 1.00 \\
\hline Other & 2.01 & 3.17 & 4.27 & 3.27 & 1.86 & 1.57 \\
\hline Sum & 93.55 & 79.23 & 93.48 & 77.40 & 96.38 & 72.96 \\
\hline
\end{tabular}

Source: Author's calculations with BEEPS 2002 dataset.

The data show that bank credit generally plays a relatively small role in the overall financing of both working capital and new investment. Borrowing from banks, however, plays a far more important role for large firms, who on average finance around 17 per cent of their working capital and new investment through bank credit. This is compared with around 13 per cent for medium firms and 7 per cent for small firms (cf. table 16). The breakdown per country also reveals a very clear relationship between bank credit and firm size. There are outliers for medium-sized firms in Estonia, Hungary, Poland, Slovak Republic and Slovenia, but the pattern as such is very clear. That is, large firms do rely on bank finance to a much greater extent than small and medium enterprises. Romania appears to be the only country where the differences between small, medium and large firms in bank financing are relatively low. Bank lending in virtually all other ACs shows strong distinctions with respect to firm size. 
And while bank lending in general appears to be a limited source of finance, especially for small firms, borrowing from foreign banks seems to be almost negligible. In general, BEEPS indicates that borrowing from local private banks seems to be more important than borrowing from state-owned banks (including state development banks), which again play a more significant role than foreign banks. This result is somewhat puzzling, given the fact that foreign-owned banks hold on average about 70 per cent of all assets in the ACs.

Table 16: Borrowing from banks (local private commercial, state-owned and foreign banks, in per cent)

\begin{tabular}{|c|c|c|c|c|c|c|}
\hline & \multicolumn{2}{|c|}{ Large firms } & \multicolumn{2}{|c|}{ Medium firms } & \multicolumn{2}{|c|}{ Small firms } \\
\hline & $\begin{array}{c}\text { Working } \\
\text { capital }\end{array}$ & $\begin{array}{c}\text { New } \\
\text { investment }\end{array}$ & $\begin{array}{c}\text { Working } \\
\text { capital }\end{array}$ & $\begin{array}{c}\mathrm{New} \\
\text { investment }\end{array}$ & $\begin{array}{c}\text { Working } \\
\text { capital }\end{array}$ & $\begin{array}{c}\text { New } \\
\text { investment }\end{array}$ \\
\hline AC-10 & 17.09 & 17.54 & 13.40 & 12.95 & 6.96 & 7.61 \\
\hline Bulgaria & 16.74 & 18.94 & 12.16 & 10.01 & 8.76 & 5.75 \\
\hline $\begin{array}{l}\text { Czech } \\
\text { Republic }\end{array}$ & 21.97 & 22.23 & 12.40 & 12.07 & 6.75 & 9.39 \\
\hline Estonia & 9.78 & 10.09 & 9.58 & 11.50 & 5.04 & 4.31 \\
\hline Hungary & 19.12 & 28.69 & 24.74 & 15.53 & 6.14 & 10.11 \\
\hline Latvia & 10.84 & 20.60 & 8.84 & 15.00 & 3.47 & 2.74 \\
\hline Lithuania & 14.69 & 15.47 & 12.03 & 6.00 & 4.02 & 3.02 \\
\hline Poland & 21.33 & 14.83 & 14.92 & 16.56 & 8.78 & 10.09 \\
\hline Romania & 12.90 & 10.00 & 12.22 & 7.94 & 10.74 & 9.41 \\
\hline $\begin{array}{l}\text { Slovak } \\
\text { Republic }\end{array}$ & 16.45 & 13.16 & 8.69 & 15.40 & 3.07 & 3.47 \\
\hline Slovenia & 17.84 & 16.84 & 13.80 & 19.20 & 8.15 & 11.47 \\
\hline
\end{tabular}

Source: Author's calculations with BEEPS 2002 dataset.

A possible explanation would be that foreign banks tend to finance a rather small number of large projects, so that while the foreign banks' share of overall banking assets is highly important, financing through foreign banks is of minor importance for many firms. This explanation would support the hypothesis that foreign-owned banks are not engaged in much financing of small businesses. This explanation, however, would need further qualification and cannot be taken as a definite conclusion of the BEEPS.

A more likely explanation is that a great number of the firms questioned for the BEEPS simply may not be aware of the fact that their house bank is foreign-owned. For instance, the results in annex 6 would suggest that in Estonia virtually no medium or small firm gets financing from foreign banks, although foreign banks hold nearly 100 per cent of all banking assets in the country. This seems highly implausible. It is rather likely that customers of Hansapank and Eesti Ühispank still regard them as local banks, although they are actually Swedish-owned.

Nevertheless, the findings are very straightforward when leaving aside the distinction between types of banks. Small firms receive less financing from banks than medium-sized firms, which again receive less than larger firms. 


\subsection{EFFECTS OF BANKING COMPETITION AND CONCENTRATION ON SME FINANCE}

In the previous sections we have seen that while financing conditions have improved over the past years, the level of financial deepening is nevertheless very low. Access to finance still constitutes a problem in most ACs. This is particularly true for SMEs.

It is widely acknowledged that the underdevelopment of domestic financial markets mainly constrains the growth of relatively small and medium businesses. Larger firms find it easier to overcome local financial market imperfections by raising funds abroad, where they are more abundant and available. In a study for the European Commission, Gianetti et al. (2002, p. 3) point out that "if financial market integration among European countries helps develop local financial markets or widens the geographical limits within which SMEs can raise funds, it will prompt a disproportionate growth of SMEs." The question, however, is whether this will be the case. As discussed in section one, financial integration should theoretically increase the overall supply of finance. This section will discuss whether this improvement will also reach SMEs or if the benefits of financial integration will mostly advance financing conditions for large enterprises, leaving SMEs aside.

While financial integration - especially through the presence of foreign banks - is likely to spur the efficiency of the financial intermediaries and markets of financially less developed countries, this section argues that the restructuring of the ACs' financial sectors might mostly benefit larger companies while SMEs will be left on their own. The reasoning is as follows: as pointed out by Chick (2000), financial markets are not like other businesses and competition cannot be expected to produce results similar to those in ordinary business. In particular, competition is likely to entail concentration in the banking sector. The central importance of banking is its relationship with other businesses. If banking becomes more concentrated and dominated by foreign banks - a process that can already be observed in the ACs - large companies will be favoured recipients of loans and other financial services whereas small and medium companies, especially in peripheral regions, will find it more difficult to get finance.

In a perfect market situation, where all information is readily available to all parties, there would be no such financing gap. But reality is characterised by market imperfections which are due to information asymmetry. Because the lender cannot easily assess the riskiness of the borrower's project, it is a costly exercise to obtain information regarding the quality of the business and its management. In their seminal contribution Stiglitz and Weiss (1981) showed that this lack of information may lead credit institutions to adverse selection and thus credit rationing. In order not to crowd out the borrowers with good risk who are only willing to pay lower interest rates, the rates are set below the market clearing level with a resulting shortage of available funds.

If financial markets are undergoing major structural adjustments due to increased competition, this is likely to have an impact on the relationship between banks and borrowers. Relationship lending is of particular importance to SMEs. Under relationship lending, according to Berger, Klapper and Udell (2001, pp. 2,129-2,130), "information is gathered by the lender beyond the relatively transparent data available in the financial statements and other sources readily available at the time of origination. The information is gathered through contact over time with the firm, its owner, and its local community on a variety of dimensions. The lender may gather data from the provision of past loans and other services to the business. Information may also be garnered from contact with the borrower's customers and suppliers, and from the lender's knowledge of the borrower's interaction with the local community. This information is used in making additional decisions over time regarding renewals, additional loans, renegotiations, and monitoring strategies, and is not shared with other potential lenders. The 
production of relationship information is costly, and the costs are likely to be passed on to the relationship borrowers."

The counterpart to relationship lending is pure transactions lending, under which due diligence and contract terms are based on information that is relatively easily on hand. Each transaction stands on its own, and information from the relationship between the lender and the borrower, if any, is irrelevant (Berger, Klapper and Udell, 2001, p. 2,130).

The so-called large-bank barriers hypothesis claims that large banks tend to have difficulty extending relationship loans to informationally opaque small businesses (Berger, Klapper and Udell, 2001, p. 2,131). Large banks, which typically provide transaction lending and other wholesale capital market services to large corporate customers, tend to have organisational structures that are designed for efficient transaction-based lending. This lending is based on "hard" information such as quantitative financial ratios, collateral and credit scores. They often offer standardised credit policies based on easily observable, verifiable, and transmittable data. In contrast, relationship information often involves "soft" data, e.g. information about the character and reliability of the firm's owner, and may be more difficult to quantify, verify and communicate through the layers of management and ownership of large banking organisations (Berger and Udell, 2002). Furthermore, large banks may find it more difficult to engage in relationship lending than locally-owned institutions, as relationship lending may require local knowledge which large banks that are headquartered away will find more difficult to build up (Berger, Klapper and Udell, 2001, p. 2,131).

A large body of empirical work seems to support the large-bank barriers hypothesis. For example, Berger, Kashyap and Scalise (1995) find that large banks in the US tend to devote a lower proportion of their assets to small business lending than smaller institutions. Haynes et al. (1999) find that large banks lend to larger, older and more financially secure businesses relatively more often than do small banks. That is, they seem to focus on firms that are most likely to receive transactions loans. Another study by Goldberg et al. (2002) finds that large banks have a tendency to base their small business loan approval decisions more on financial ratios, while the existence of a previous relationship with the borrowing firm mattered more to small banks. ${ }^{30}$

How does this relate to the ACs? While there is no data available to statistically confirm or refute the large-bank barriers hypothesis for the ACs' banking sectors, the increasing dominance of large banks in the region can be assessed. Increased competition is likely to reduce the local monopoly power of small local banks but increase the market power of the large money centre banks (Chick and Dow, 1994). While the banking system as a whole will as a result be more unconstrained in its power to create credit, the large-bank barriers hypothesis supposes that some constraints on credit availability to small enterprises will be preserved, and additional constraints introduced.

As can be seen from table 17, concentration in the banking sector is relatively high in all ACs. With the exception of Bulgaria, Hungary and Poland, the market shares of the five largest banks in the ACs is markedly higher than the unweighted average of 55 per cent for the EU15 countries.

\footnotetext{
${ }^{30}$ For further references see Berger, Klapper and Udell (2001, pp. 2,131-3).
} 
Table 17: Total assets of five largest banks relative to total assets of all banks (in per cent)

\begin{tabular}{lcccccccccc}
\hline & $\mathbf{1 9 9 3}$ & $\mathbf{1 9 9 4}$ & $\mathbf{1 9 9 5}$ & $\mathbf{1 9 9 6}$ & $\mathbf{1 9 9 7}$ & $\mathbf{1 9 9 8}$ & $\mathbf{1 9 9 9}$ & $\mathbf{2 0 0 0}$ & $\mathbf{2 0 0 1}$ & $\mathbf{2 0 0 2}$ \\
\hline \hline Bulgaria & na & na & na & na & na & 0.62 & 0.62 & 0.61 & 0.57 & 0.55 \\
Czech & 0.81 & 0.74 & 0.70 & 0.69 & 0.67 & 0.66 & 0.65 & 0.66 & 0.68 & 0.66 \\
Republic & 0.69 & 0.68 & 0.75 & 0.78 & 0.87 & 1.00 & 0.99 & 0.99 & 0.99 & 0.99 \\
Estonia & 0.69 & 0.59 & \\
Hungary & 0.72 & 0.66 & 0.59 & 0.58 & 0.53 & 0.54 & 0.54 & 0.53 & 0.57 & 0.55 \\
Latvia & na & 0.51 & 0.53 & 0.52 & 0.51 & 0.61 & 0.61 & 0.62 & 0.66 & 0.65 \\
Lithuania & na & na & 0.76 & 0.80 & 0.84 & 0.90 & 0.91 & 0.88 & 0.88 & 0.84 \\
Poland & 0.55 & 0.53 & 0.53 & 0.51 & 0.48 & 0.45 & 0.50 & 0.49 & 0.53 & 0.56 \\
Romania & na & na & na & na & 0.76 & 0.70 & 0.67 & 0.70 & 0.71 & 0.68 \\
Slovak & 0.87 & 0.82 & 0.75 & 0.68 & 0.63 & 0.60 & 0.59 & 0.63 & 0.67 & 0.67 \\
Republic & & & & & & & & & & \\
Slovenia & na & 0.62 & 0.63 & 0.63 & 0.62 & 0.63 & 0.63 & 0.63 & 0.69 & 0.69 \\
\hline
\end{tabular}

Source: EBRD country database.

Another indicator for increased competition and consolidation in the ACs' banking sectors is the number of banking institutions as shown in table 18. The number of banks decreased markedly over the past years. Between 1995 and 2002, the number of banks decreased by 63 per cent in Estonia, 45 per cent in Latvia, 43 per cent in Slovenia, 39 per cent in the Slovak Republic, 32 per cent in the Czech Republic and 27 per cent in Poland. The only country to register a rise in the number of banks between 1995 and 2002 is Romania. ${ }^{31}$

Table 18: Number of banks (of which foreign owned) 1995-2002

\begin{tabular}{lcccccccc}
\hline Country & $\mathbf{1 9 9 5}$ & $\mathbf{1 9 9 6}$ & $\mathbf{1 9 9 7}$ & $\mathbf{1 9 9 8}$ & $\mathbf{1 9 9 9}$ & $\mathbf{2 0 0 0}$ & $\mathbf{2 0 0 1}$ & $\mathbf{2 0 0 2}$ \\
\hline \hline Bulgaria & $41(3)$ & $42(3)$ & $28(7)$ & $34(17)$ & $34(22)$ & $35(25)$ & $35(26)$ & $34(26)$ \\
Czech & $55(23)$ & $53(23)$ & $50(24)$ & $45(25)$ & $42(27)$ & $40(26)$ & $38(26)$ & $37(26)$ \\
Republic & $19(5)$ & $15(4)$ & $12(4)$ & $6(3)$ & $7(3)$ & $7(4)$ & $7(4)$ & $7(4)$ \\
Estonia & $43(21)$ & $42(24)$ & $45(30)$ & $44(28)$ & $43(29)$ & $42(33)$ & $41(31)$ & $38(27)$ \\
Hungary & $42(11)$ & $35(14)$ & $32(15)$ & $27(15)$ & $23(12)$ & $21(12)$ & $23(10)$ & $23(9)$ \\
Latvia & $15(0)$ & $12(3)$ & $12(4)$ & $12(5)$ & $13(4)$ & $13(6)$ & $13(6)$ & $14(7)$ \\
Lithuania & $81(18)$ & $81(25)$ & $83(29)$ & $83(31)$ & $77(39)$ & $74(47)$ & $64(46)$ & $59(45)$ \\
Poland & $24(8)$ & $31(10)$ & $33(13)$ & $36(16)$ & $34(19)$ & $33(21)$ & $33(24)$ & $31(24)$ \\
Romania & $33(18)$ & $29(14)$ & $29(13)$ & $27(11)$ & $25(11)$ & $23(14)$ & $21(13)$ & $20(15)$ \\
Slovak & $39(6)$ & $36(4)$ & $34(4)$ & $30(3)$ & $31(5)$ & $28(6)$ & $24(5)$ & $22(6)$ \\
Republic & 392 & 376 & 358 & 344 & 329 & 316 & 299 & 285 \\
Slovenia & $395)$ & $(124)$ & $(143)$ & $(154)$ & $(171)$ & $(194)$ & $(191)$ & $(189)$ \\
AC-10 & $(113)$ & $(124)$ & & & & & & \\
\end{tabular}

Source: EBRD country database.

Table 19 shows that the consolidation process in banking and finance has been going on quite briskly over the past years, but it seems to have slowed down recently. The effects of merger and acquisition (M\&A) activities in banking on small business lending have also been scrutinised in a number of studies. These usually found that M\&As involving large banking organisations reduced small business lending substantially. ${ }^{32}$

\footnotetext{
${ }^{31}$ In 1998-99, there was a restructuring programme in Romania, in the course of which the largest Romanian bank, Bancorex, was closed down and bad assets were transferred to a Bank Resolution Agency. Since 1998, the number of banks in Romania actually decreased.

${ }^{32}$ The following statement by Pavel Racocha $(2003$, p. 2), a member of the board of the Czech National Bank, displays that this view has been common also among the ACs' authorities: "In the
} 
Table 19: Completed M\&A in banking, insurance and financial services

\begin{tabular}{lccccc}
\hline & $\mathbf{5 1 9 9 9}$ & $\mathbf{2 0 0 0}$ & $\mathbf{2 0 0 1}$ & $\mathbf{2 0 0 2}$ & $\mathbf{2 0 0 3}$ \\
\hline \hline Bulgaria & 3 & 5 & 5 & 12 & 7 \\
Czech Republic & 17 & 17 & 10 & 12 & 12 \\
Estonia & 19 & 12 & 2 & 6 & 1 \\
Hungary & 20 & 16 & 17 & 11 & 9 \\
Latvia & 12 & 7 & 5 & 5 & 1 \\
Lithuania & 8 & 7 & 6 & 4 & 5 \\
Poland & 42 & 30 & 27 & 26 & 14 \\
Romania & 8 & 4 & 6 & 4 & 5 \\
Slovak Republic & 2 & 4 & 10 & 8 & 4 \\
Slovenia & 0 & 1 & 4 & 2 & 3 \\
\hline
\end{tabular}

Source: Bureau Van Dijk/ZEPHYR.

The analysis of the BEEPS data in the previous section showed a very clear positive relationship between the size of firms and their financing through bank credit. Whereas the BEEPS makes no distinction between large and small banks, and thus cannot be employed to empirically verify or refute the large-bank barriers hypothesis, the fact that the ACs' banking sectors are highly concentrated and hence dominated by larger banks gives reason to assume that large banks in the ACs indeed do not extend their services to small enterprises on the same scale as they do to large businesses.

Another issue is the dominance of foreign banks. The foreign-owned-bank barriers hypothesis states that foreign-owned banks are less likely to lend to informationally opaque small businesses than domestically-owned banks (cf. Berger, Klapper and Udell, 2001, pp. 2,133-5). The argument is similar to the large-bank barriers hypothesis: because banks entering a foreign market are likely to be large and headquartered far away from small local businesses, they will find it difficult to extend relationship lending to these borrowers. In addition, cultural and language barriers, as well as non-familiarity with the local markets, may make it more difficult and hence costly to gather and process locally-based relationship information. ${ }^{33}$ Empirical evidence also seems to support this hypothesis. Clarke et al. (2001, p. 20), for example, note that "In general, foreign banks appear to allocate greater shares of their lending portfolios to commercial and industrial loans, providing indirect evidence that foreign banks may be more important in the market for loans to large companies."

In section 2.5 we discussed the dominance of foreign banks, with foreign investors currently owning more than two-thirds of the banking system of the ACs as a whole. In 2002, 189 out of the 285 commercial banks in the region were controlled by foreign owners, with a strong tendency towards larger institutions (cf. table 18). The presence of foreign banks is likely to increase in the course of the next years, particularly as a result of the EU's single passport

Czech Republic, the privatization of banks had been delayed for several years due to the government's belief that privatized banks would stop providing soft loans to strategically important firms. This fear was underlined by the experience with foreign banks that were entering the market since 1992 and cherry-picking their clients." For references on the effects of M\&As in banking on small business lending see Berger, Klapper and Udell (2001, p. 2,132).

${ }^{33}$ A qualification needs to be made concerning the way foreign banks enter the market. A major reason for market entry through the acquisition of domestic banks is to get hold on the local knowledge of the bank's management and staff and the already existing business relations of these banks. One would thus expect foreign banks to carefully maintain this local knowledge, making the argument of the foreign-owned-bank barriers hypothesis a less strong one if they enter the market through M\&As. 
policy. This allows a bank that is registered in one EU member state to open branches in other member countries on the basis of home licences alone. The single passport policy has also been applicable to the new member states since 1 May 2004.

Again, the BEEPS data cannot be employed to affirm the foreign-owned-bank barriers hypothesis. But given that (with the exception of Slovenia) the ACs' banking sectors are highly dominated by foreign-owned institutions, the results of the BEEPS analysis present a picture that would rather support this hypothesis. Interestingly, firms in Slovenia, the country with the lowest foreign-bank penetration, are amongst those with the least complaints about access to finance (cf. annex 4).

If the large-bank barriers hypothesis and the foreign-owned-bank barriers hypothesis apply, this could imply that the structures of the ACs' banking systems as they have evolved over the past decade will pose a serious constraint to the development of SMEs. Further, SMEs might not see an improvement in their financing conditions on the scale that will be the case for larger enterprises.

In addition to increasing competition in banking, the local stock exchanges will increasingly face problems competing with the major financial centres of the west, and their future might be in question (see Claessens et al., 2003). While larger firms will find much more favourable financing conditions as they can raise funds both domestically and overseas, the majority of small and medium-sized firms will not be able to go directly overseas. Since these firms are important for economic growth and need to raise capital, a decline in local market activity could prove to be a costly outcome for the ACs. 
This paper started with a brief discussion of the linkages between financial integration, financial development and economic growth. It then went on to look at the degree of financial integration between the ACs and the western European financial markets. While most of the indicators were able to show an overall trend of increasing convergence and integration, it is particularly the foreign bank penetration indicators that display the real dimension of financial integration with the "old" EU member states.

The paper then turned to look at the financing conditions of businesses in the ACs. Despite great improvements, the ACs' banking sectors are still fairly underdeveloped and financing conditions persist to severely constrain the development of the private sector. Access to finance particularly proves to be a problem for SMEs. The paper argues that the increasing dominance of large and foreign banking institutions in almost all ACs might pose problems to the development of SMEs. These enterprises play a crucial role in the development of the private sector, and hence economic growth. While financial integration and the dominance of foreign banks will make the banking systems more unconstrained in their power to create credit, this might largely benefit larger businesses, leaving small and medium enterprises aside. The large-bank barriers hypothesis and the foreign-owned-bank barriers hypothesis suppose that large and foreign institutions have problems extending loans to smaller entities. In the ACs, it is especially these banking institutions that dominate the market, suggesting that SMEs might not see an improvement in their financing conditions on the scale that will be the case for larger enterprises.

The analysis of the BEEPS data covering information on 2,427 enterprises in the ACs showed a clear pattern regarding firms' access to finance. In general, small firms appear to have much larger problems in getting funding than medium and large enterprises. Furthermore, an analysis of the sources of finance for working capital and investment gave evidence of a strong positive relationship between the size of firms and their financing through bank credit. While these results cannot be taken as sufficient empirical proof of the large-bank barriers hypothesis and the foreign-owned-bank barriers hypothesis, they do support these hypotheses.

Also the national and European authorities have started to become aware of this problem. ${ }^{34}$ For example, in a recent report, the European Commission recognises that the need to promote entrepreneurship in Europe requires focused public action to close gaps in the availability of market finance for small businesses. In particular, "the accession and candidate countries need to pay attention to the further development of their financial systems. This includes capacity building throughout the financial sector making it easier for banks to become more acquainted with SMEs and more willing to provide medium and long-term lending. Furthermore, a gradual emergence of an equity culture will open the way for a more developed venture capital industry." (European Commission, 2003a, p. 7)

However, despite these issues, one should not paint a too gloomy picture in regard to foreign bank penetration. The entrance of foreign banks has significantly increased the standards and the efficiency of the ACs' banking systems. Bokros (2001, p. 17), for example, states that "Foreign strategic investment in most lending banks has proved to be an unqualified success in both Poland and Hungary, after several consecutive efforts of government-orchestrated and government-financed consolidation of insolvent state-owned banks. Foreign strategic partners have been able and willing to provide not only much-needed additional capital and

\footnotetext{
${ }^{34}$ For an overview on European and national schemes to support SMEs' access to finance in old and new member states see European Commission (2003a) and (2003b). For a discussion of how the financing gap for small businesses might be addressed see Tucker and Lean (2003).
} 
management skills but also product development and innovation, modernization of risk management and treasury operations, internal audit and control, and information technology." Similarly, Guarco et al. (2003, p. 77) state that "By and large western ownership and control have proven highly beneficial to banks in CEE [central and eastern Europe]. They brought expertise, in the form of product knowledge, risk management, or technology. They brought advantages for funding and capitalization, as well as a welcome shield against government interference."

Furthermore, if improved efficiency in the banking system results in an expansion in total lending, the amount of lending to SMEs might increase even if the share of lending to them falls. Also, increased pressure from the presence of foreign banks might cause smaller and domestic banks to modify their behaviour and make them seek new market niches (Clarke et al., 2002, p. 21). A focus of large and foreign banking institutions on providing financial services to larger corporations could offer opportunities for small local banks to extend their services particularly to SMEs. Nevertheless, to ensure a favourable business environment also for small businesses, both national and European financial services authorities need to keep an eye on these developments, and be ready to step in if appropriate. 


\section{REFERENCES}

Bank for International Settlements (2003), Guide to international banking statistics, Basel.

A. N. Berger, R. De Young and G. F. Udell (2001), "Efficiency barriers to the consolidation of the European financial services industry," European Financial Management, Vol. 7, Issue 1, pp. 117-130.

A. N. Berger, A. K. Kashyap and J. Scalise (1995), "The transformation of the U.S. banking industry: what a long, strange trip it's been," Brookings Papers on Economic Activity, Vol. 1995, No. 2, pp. 55-218.

A. N. Berger, L. F. Klapper and G. F. Udell (2001), "The ability of banks to lend to informationally opaque small businesses," Journal of Banking \& Finance, Vol. 25, pp. 2,1272,167 .

A. N. Berger and G. F. Udell (2002), "Small business credit availability and relationship lending: the importance of bank organisational structure," The Economic Journal, Vol. 112, Issue 477, pp. F32-F53.

L. Bokros (2001), "A perspective on financial sector development in Central and Eastern Europe," in: L. Bokros, A. Fleming and C. Votava (eds.), Financial transition in Europe and Central Asia. Challenges of the new decade, The World Bank, Washington.

C. M. Buch, J. Kleinert and P. Zajc (2003), "Foreign bank ownership: a bonus or threat for financial stability?" in: SUERF Studies 2003/4, Securing financial stability: problems and prospects for new EU members, Vienna, pp. 45-83.

G. Caviglia, G. Krause and C. Thimann (2002), "Key features of the financial sectors in EU accession countries," in: C. Thimann (ed.), Financial sectors in EU accession countries, European Central Bank, Frankfurt am Main, pp. 15-30.

V. Chick (2000), "Big banks, small business and the regions in bankers' Europe," in: J. Toporowski (ed.), Political economy and the new capitalism. Essays in honour of Sam Aaronovitch, Routledge, London and New York.

V. Chick and S. Dow (1994), "Competition and the future of the European banking and financial system," UCL Department of Economics Discussion Paper 94-16, London.

S. Claessens, R. Lee and J. Zechner (2003), The future of stock exchanges in European Union accession countries, Corporation of London, London.

G. Clarke, R. Cull and M. S. Martinez Peria (2002), "Does foreign bank penetration reduce access to credit in developing countries? Evidence from asking borrowers," revised version of Working Paper No. 2716, The World Bank, Washington.

G. Clarke, R. Cull, M. S. Martinez Peria and S. M. Sanchez (2001), "Foreign bank entry: experience, implications for developing countries, and agenda for further research," Working Paper No. 2698, The World Bank, Washington.

G. De Brouwer (1997), "Interest parity conditions as indicators of financial integration in East Asia,” Pacific Economic Paper No. 268, Australia-Japan Research Centre, Canberra.

R. T. De Haas and I. P. Van Lelyveld (2004), "Foreign bank penetration and private sector credit in Central and Eastern Europe," Journal of Emerging Market Finance, forthcoming.

EBRD (2002), Transition report 2002. Agriculture and rural transition, London.

EBRD (2003), Transition report 2003. Integration and regional cooperation, London. 
ECB (2004), Financial FDI to the EU accession countries, Directorate General International and European Relations, 19 March 2004, Frankfurt am Main.

European Commission (2003a), Access to finance for small and medium-sized enterprises, http://europa.eu.int/comm/enterprise/entrepreneurship/financing/docs/com(2003)713 en.pdf.

European Commission (2003b), Microcredit for small businesses and business creation: bridging the market gap, http://europa.eu.int/comm/enterprise/entrepreneurship/financing/ docs/microcredit_report_en.pdf.

S. Fries, T. Lysenko and S. Polenac (2003), "The 2002 business environment and enterprise performance survey: results from a survey of 6,100 Firms," EBRD Working Paper No. 84, London.

S. Fries and A. Taci (2004), "Cost efficiency of banks in transition: evidence from 289 banks in 15 post-communist countries," EBRD Working Paper No. 86, London. Forthcoming in the Journal of Banking and Finance.

M. Gianetti, L. Guiso, T. Jappelli, M. Padula and M. Pagano (2002), "Financial market integration, corporate financing and economic growth," European Commission Economic Papers No. 179, Brussels.

L. G. Goldberg, R. A. Cole and L. J. White (2002), "Cookie-cutter versus character: the micro structure of small business lending by large and small banks," EFA 2002 Berlin Meetings Discussion Paper, http://ssrn.com/abstract=300702.

D. Gros and K. Lannoo (2000), The euro capital market, John Wiley \& Sons, New York.

P. Guarco, S. Theodore and E. Jackson Moore (2003), "Emerging market banks. A world of difference," in: Euromoney, August 2003, pp. 76-80.

G. W. Haynes, C. Ou and R. Berney (1999), "Small business borrowing from large and small banks," in J. L. Blanton, A. Williams and S. L.W. Rhine (eds.), Business access to capital and credit. A Federal Reserve System research conference, Federal Reserve Bank of Chicago, pp. 287-327.

P. R. Krugman (1991), Geography and trade, MIT Press, Cambridge, MA.

P. R. Lane and G. M. Milesi-Ferretti (2003), "International financial integration," IMF Staff Papers, Vol. 50, Special Issue, pp. 82-113.

K. Lanoo and C. Stirböck (2000), "The Central and Eastern European countries on their way to EU membership," in: M. Schröder (ed.), The new capital markets in Central and Eastern Europe, Springer, Berlin et al.

R. Levine (2003), "Finance and growth: theory, evidence and mechanisms", mimeo, University of Minnesota.

G. Myrdal (1957), Economic theory and underdeveloped regions, Duckworth, London.

OECD (2001), Economic surveys: Czech Republic, July, Paris.

OECD (2002), Economic surveys: Slovak Republic, Volume 2002/11, June, Paris.

T. Padoa-Schioppa (2001), "Financial integration in western Europe: can the east catch up?" in: L. Bokros, A. Fleming and C. Votava (eds.), Financial transition in Europe and Central Asia. Challenges of the new decade, The World Bank, Washington.

M. Pagano (1993), "Financial markets and growth: an overview," European Economic Review, Vol. 37, pp. 613-622. 
P. Racocha (2003), "Joining the EU - impact on the financial sector of new member states," BIS Review, 53/2003.

B. Reszat (2003), "How has the European monetary integration process contributed to regional financial market integration?” HWWA Discussion Paper No. 221, Hamburg.

J. E. Stiglitz and A. Weiss (1981), "Credit rationing in markets with imperfect information," American Economic Review, Vol. 71, June, pp. 393-410.

M. Thiel (2001), "Finance and economic growth - a review of theory and the available evidence," European Commission, Directorate-General for Economic and Financial Affairs, Economic Paper No. 158, July, Brussels.

A. P. Thirlwall (2000), The euro and regional divergence in Europe, New Europe Research Trust, London.

J. Tucker and J. Lean (2003), "Small firm finance and public policy," Journal of Small Business and Enterprise Development, Vol.10, pp.50-61.

L. Weill (2003), "Banking efficiency in transition economies: the role of foreign ownership," Economics of Transition, Vol. 11, pp. 569-592. 
Annex 1.1: Foreign claims of reporting banks on individual countries (in millions of US dollars)

by nationality of reporting banks, end-September 2003

\begin{tabular}{lrrc}
\hline Claims vis-à-vis & $\begin{array}{c}\text { Total foreign } \\
\text { claims }\end{array}$ & $\begin{array}{c}\text { Claims of EU- } \\
\mathbf{1 3}^{*}\end{array}$ & $\begin{array}{c}\text { Claims of EU-13 as per cent } \\
\text { of total foreian claims }\end{array}$ \\
\hline \hline All countries & $14,658,959$ & $8,672,237$ & 59.16 \\
EU-15 & $7,022,609$ & $4,486,053$ & 63.88 \\
AC-10 & 227,864 & 195,430 & 85.77 \\
Bulgaria & 3,244 & 2,654 & 81.81 \\
Czech Republic & 49,979 & 45,574 & 91.19 \\
Estonia & 7,877 & 7,706 & 97.83 \\
Hungary & 45,746 & 39,125 & 85.53 \\
Latvia & 3,873 & 3,718 & 96.00 \\
Lithuania & 5,687 & 5,398 & 94.92 \\
Poland & 80,909 & 64,518 & 79.74 \\
Romania & 6,748 & 5,257 & 77.9 \\
Slovak Republic & 15,356 & 14,121 & 91.96 \\
Slovenia & 8,445 & 7,359 & 87.14 \\
\hline
\end{tabular}

\begin{tabular}{|c|c|c|c|c|c|c|c|c|c|c|c|c|c|c|c|c|c|}
\hline $\begin{array}{l}\text { Claims vis-à- } \\
\text { vis }\end{array}$ & Austria & Belgium & Canada & Denmark & Finland & France & Germany & Ireland & Italy & Japan & Netherlands & Portugal & Spain & Sweden & Switzerland & $\begin{array}{c}\text { United } \\
\text { Kingdom }\end{array}$ & $\begin{array}{l}\text { United } \\
\text { States }\end{array}$ \\
\hline All countries & 94,380 & 572,571 & 356,531 & 73,821 & 49,007 & $1,281,317$ & $2,476,050$ & 350,258 & 320,841 & $1,187,650$ & $1,174,549$ & 59,467 & 375,116 & 203,645 & $1,481,685$ & $1,641,215$ & 784,624 \\
\hline EU-15 & 51,207 & 403,910 & 84,822 & 56,658 & 28,030 & 631,884 & $1,430,570$ & 283,715 & 176,525 & 414,872 & 632,172 & 42,673 & 173,776 & 133,512 & 575,222 & 441,421 & 363,516 \\
\hline AC-10 & 14,415 & 37,058 & 443 & 0 & 2,435 & 13,418 & 66,313 & 0 & 29,478 & 1,811 & 16,119 & 121 & 822 & 13,589 & 1,572 & 1,662 & 12,898 \\
\hline Bulgaria & 99 & 24 & & & & 298 & 1,147 & & 847 & 61 & 215 & & 9 & 2 & 114 & 13 & 221 \\
\hline Czech Republic & 4,239 & 19,504 & & & & 6,271 & 10,572 & & 1,881 & 181 & 2,780 & 46 & 270 & 11 & 113 & & 2,030 \\
\hline Estonia & 56 & 30 & & & 1,132 & 5 & 618 & & 59 & 35 & 33 & & 1 & 5,769 & 6 & 3 & 13 \\
\hline Hungary & 3,129 & 6,814 & 238 & & 10 & 1,723 & 19,413 & & 5,129 & 407 & 2,039 & 14 & 199 & 35 & 488 & 620 & 2,306 \\
\hline Latvia & 29 & 14 & & & 628 & 6 & 862 & & 11 & 12 & 10 & & 1 & 2,155 & 6 & 2 & 17 \\
\hline Lithuania & 104 & 18 & & & 445 & 30 & 1,424 & & 11 & 26 & 12 & 9 & 1 & 3,337 & 37 & 7 & 94 \\
\hline Poland & 3,874 & 7,798 & 205 & & 217 & 1,949 & 25,008 & & 14,235 & 856 & 8,186 & 48 & 275 & 2,112 & 561 & 816 & 6,667 \\
\hline Romania & 390 & 69 & & & 3 & 940 & 1,535 & & 536 & 15 & 1,592 & & 16 & 71 & 75 & 105 & 805 \\
\hline Slovak Republic & 1,209 & 2,198 & & & & 458 & 2,555 & & 6,363 & 128 & 1,144 & & 14 & 94 & 153 & 86 & 732 \\
\hline Slovenia & 1,286 & 589 & & & & 1,738 & 3,179 & & 406 & 90 & 108 & 4 & 36 & 3 & 19 & 10 & 13 \\
\hline
\end{tabular}

Sources: BIS Consolidated Banking Statistics, third quarter 2003, January 2004, Table 9 and EBRD country database.

* EU-13 comprises the EU-15 countries minus Greece and Luxemburg, whose banks are not listed in the BIS Consolidated Banking Statistics. 
Annex 1.2: Foreign claims on individual recipient countries as per cent of total foreign claims

\begin{tabular}{|c|c|c|c|c|c|c|c|c|c|c|c|c|c|c|c|c|c|c|c|}
\hline $\begin{array}{l}\text { Claims vis-à- } \\
\text { vis }\end{array}$ & $\begin{array}{c}\text { Total } \\
\text { foreign } \\
\text { claims } \\
\end{array}$ & EU-13* & Austria & Belgium & Canada & Denmark & Finland & France & Germany & Ireland & Italy & Japan & Netherlands & Portugal & Spain & Sweden & Switzerland & $\begin{array}{l}\text { United } \\
\text { Kingdom }\end{array}$ & $\begin{array}{l}\text { United } \\
\text { States }\end{array}$ \\
\hline All countries & 100.0 & 100.0 & 100.0 & 100.0 & 100.0 & 100.0 & 100.0 & 100.0 & 100.0 & 100.0 & 100.0 & 100.0 & 100.0 & 100.0 & 100.0 & 100.0 & 100.0 & 100.0 & 100.0 \\
\hline EU-15 & 47.9 & 51.7 & 54.3 & 70.5 & 23.8 & 76.8 & 57.2 & 49.3 & 57.8 & 81.0 & 55.0 & 34.9 & 53.8 & 71.8 & 46.3 & 65.6 & 38.8 & 26.9 & 46.3 \\
\hline AC-10 & 1.6 & 2.3 & 15.3 & 6.5 & 0.1 & 0.0 & 5.0 & 1.0 & 2.7 & 0.0 & 9.2 & 0.2 & 1.4 & 0.2 & 0.2 & 6.7 & 0.1 & 0.1 & 1.6 \\
\hline Bulgaria & 0.0 & 0.0 & 0.1 & 0.0 & 0.0 & 0.0 & 0.0 & 0.0 & 0.0 & 0.0 & 0.3 & 0.0 & 0.0 & 0.0 & 0.0 & 0.0 & 0.0 & 0.0 & 0.0 \\
\hline Czech Republic & 0.3 & 0.5 & 4.5 & 3.4 & 0.0 & 0.0 & 0.0 & 0.5 & 0.4 & 0.0 & 0.6 & 0.0 & 0.2 & 0.1 & 0.1 & 0.0 & 0.0 & 0.0 & 0.3 \\
\hline Estonia & 0.1 & 0.1 & 0.1 & 0.0 & 0.0 & 0.0 & 2.3 & 0.0 & 0.0 & 0.0 & 0.0 & 0.0 & 0.0 & 0.0 & 0.0 & 2.8 & 0.0 & 0.0 & 0.0 \\
\hline Hungary & 0.3 & 0.5 & 3.3 & 1.2 & 0.1 & 0.0 & 0.0 & 0.1 & 0.8 & 0.0 & 1.6 & 0.0 & 0.2 & 0.0 & 0.1 & 0.0 & 0.0 & 0.0 & 0.3 \\
\hline Latvia & 0.0 & 0.0 & 0.0 & 0.0 & 0.0 & 0.0 & 1.3 & 0.0 & 0.0 & 0.0 & 0.0 & 0.0 & 0.0 & 0.0 & 0.0 & 1.1 & 0.0 & 0.0 & 0.0 \\
\hline Lithuania & 0.0 & 0.1 & 0.1 & 0.0 & 0.0 & 0.0 & 0.9 & 0.0 & 0.1 & 0.0 & 0.0 & 0.0 & 0.0 & 0.0 & 0.0 & 1.6 & 0.0 & 0.0 & 0.0 \\
\hline Poland & 0.6 & 0.7 & 4.1 & 1.4 & 0.1 & 0.0 & 0.4 & 0.2 & 1.0 & 0.0 & 4.4 & 0.1 & 0.7 & 0.1 & 0.1 & 1.0 & 0.0 & 0.0 & 0.8 \\
\hline Romania & 0.0 & 0.1 & 0.4 & 0.0 & 0.0 & 0.0 & 0.0 & 0.1 & 0.1 & 0.0 & 0.2 & 0.0 & 0.1 & 0.0 & 0.0 & 0.0 & 0.0 & 0.0 & 0.1 \\
\hline Slovak Republic & 0.1 & 0.2 & 1.3 & 0.4 & 0.0 & 0.0 & 0.0 & 0.0 & 0.1 & 0.0 & 2.0 & 0.0 & 0.1 & 0.0 & 0.0 & 0.0 & 0.0 & 0.0 & 0.1 \\
\hline Slovenia & 0.1 & 0.1 & 1.4 & 0.1 & 0.0 & 0.0 & 0.0 & 0.1 & 0.1 & 0.0 & 0.1 & 0.0 & 0.0 & 0.0 & 0.0 & 0.0 & 0.0 & 0.0 & 0.0 \\
\hline
\end{tabular}

Source: BIS Consolidated Banking Statistics, third Quarter 2003, January 2004, Table 9 and author's calculations.

Annex 1.3: Foreign claims of BIS reporting banks on ACs as per cent of domestic credit

\begin{tabular}{|c|c|c|c|c|c|c|c|c|c|c|c|c|c|c|c|c|c|c|c|}
\hline $\begin{array}{l}\text { Claims vis-à- } \\
\text { vis }\end{array}$ & $\begin{array}{c}\text { Total } \\
\text { foreign } \\
\text { claims } \\
\end{array}$ & EU-13 & Austria & Belgium & Canada & Denmark & Finland & France & Germany & Ireland & Italy & Japan & Netherlands & Portugal & Spain & Sweden & Switzerland & $\begin{array}{c}\text { United } \\
\text { Kingdom }\end{array}$ & $\begin{array}{l}\text { United } \\
\text { States }\end{array}$ \\
\hline EU-15 & 56.1 & 35.8 & 0.4 & 3.2 & 0.7 & 0.5 & 0.2 & 5.0 & 11.4 & 2.3 & 1.4 & 3.3 & 5.0 & 0.3 & 1.4 & 1.1 & 4.6 & 3.5 & 2.9 \\
\hline AC-10 & 98.7 & 84.7 & 6.2 & 16.1 & 0.2 & 0.0 & 1.1 & 5.8 & 28.7 & 0.0 & 12.8 & 0.8 & 7.0 & 0.1 & 0.4 & 5.9 & 0.7 & 0.7 & 5.6 \\
\hline Bulgaria & 51.7 & 42.3 & 1.6 & 0.4 & 0.0 & 0.0 & 0.0 & 4.8 & 18.3 & 0.0 & 13.5 & 1.0 & 3.4 & 0.0 & 0.1 & 0.0 & 1.8 & 0.2 & 3.5 \\
\hline Czech Republic & 121.8 & 111.0 & 10.3 & 47.5 & 0.0 & 0.0 & 0.0 & 15.3 & 25.8 & 0.0 & 4.6 & 0.4 & 6.8 & 0.1 & 0.7 & 0.0 & 0.3 & 0.0 & 4.9 \\
\hline Estonia & 141.8 & 138.7 & 1.0 & 0.5 & 0.0 & 0.0 & 20.4 & 0.1 & 11.1 & 0.0 & 1.1 & 0.6 & 0.6 & 0.0 & 0.0 & 103.9 & 0.1 & 0.1 & 0.2 \\
\hline Hungary & 87.6 & 75.0 & 6.0 & 13.1 & 0.5 & 0.0 & 0.0 & 3.3 & 37.2 & 0.0 & 9.8 & 0.8 & 3.9 & 0.0 & 0.4 & 0.1 & 0.9 & 1.2 & 4.4 \\
\hline Latvia & 75.0 & 72.0 & 0.6 & 0.3 & 0.0 & 0.0 & 12.2 & 0.1 & 16.7 & 0.0 & 0.2 & 0.2 & 0.2 & 0.0 & 0.0 & 41.7 & 0.1 & 0.0 & 0.3 \\
\hline Lithuania & 121.4 & 115.2 & 2.2 & 0.4 & 0.0 & 0.0 & 9.5 & 0.6 & 30.4 & 0.0 & 0.2 & 0.6 & 0.3 & 0.2 & 0.0 & 71.2 & 0.8 & 0.1 & 2.0 \\
\hline Poland & 116.6 & 92.9 & 5.6 & 11.2 & 0.3 & 0.0 & 0.3 & 2.8 & 36.0 & 0.0 & 20.5 & 1.2 & 11.8 & 0.1 & 0.4 & 3.0 & 0.8 & 1.2 & 9.6 \\
\hline Romania & 76.1 & 59.3 & 4.4 & 0.8 & 0.0 & 0.0 & 0.0 & 10.6 & 17.3 & 0.0 & 6.0 & 0.2 & 17.9 & 0.0 & 0.2 & 0.8 & 0.8 & 1.2 & 9.1 \\
\hline Slovak Republic & 73.3 & 67.4 & 5.8 & 10.5 & 0.0 & 0.0 & 0.0 & 2.2 & 12.2 & 0.0 & 30.4 & 0.6 & 5.5 & 0.0 & 0.1 & 0.4 & 0.7 & 0.4 & 3.5 \\
\hline Slovenia & 50.7 & 44.2 & 7.7 & 3.5 & 0.0 & 0.0 & 0.0 & 10.4 & 19.1 & 0.0 & 2.4 & 0.5 & 0.6 & 0.0 & 0.2 & 0.0 & 0.1 & 0.1 & 0.1 \\
\hline
\end{tabular}

Sources: BIS Consolidated Banking Statistics, third quarter 2003, January 2004, Table 9, EBRD country database and Eurostat.

* EU-13 comprises the EU-15 countries minus Greece and Luxemburg, whose banks are not listed in the BIS Consolidated Banking Statistics. 
Annex 1.4: Foreign claims of BIS reporting banks on ACs as per cent of GDP

\begin{tabular}{|c|c|c|c|c|c|c|c|c|c|c|c|c|c|c|c|c|c|c|c|}
\hline $\begin{array}{l}\text { Claims vis-à- } \\
\text { vis }\end{array}$ & $\begin{array}{c}\text { Total } \\
\text { foreign } \\
\text { claims } \\
\end{array}$ & $\overline{E U-13^{*}}$ & Austria & Belgium & Canada & Denmark & Finland & France & Germany & Ireland & Italy & Japan & Netherlands & Portugal & Spain & Sweden & Switzerland & $\begin{array}{c}\text { United } \\
\text { Kingdom }\end{array}$ & $\begin{array}{l}\text { United } \\
\text { States }\end{array}$ \\
\hline EU-15 & 66.9 & 42.8 & 0.5 & 3.8 & 0.8 & 0.5 & 0.3 & 6.0 & 13.6 & 2.7 & 1.7 & 4.0 & 6.0 & 0.4 & 1.7 & 1.3 & 5.5 & 4.2 & 3.5 \\
\hline AC-10 & 41.9 & 35.9 & 2.6 & 6.8 & 0.1 & 0.0 & 0.4 & 2.5 & 12.2 & 0.0 & 5.4 & 0.3 & 3.0 & 0.0 & 0.2 & 2.5 & 0.3 & 0.3 & 2.4 \\
\hline Bulgaria & 16.3 & 13.3 & 0.5 & 0.1 & 0.0 & 0.0 & 0.0 & 1.5 & 5.8 & 0.0 & 4.2 & 0.3 & 1.1 & 0.0 & 0.0 & 0.0 & 0.6 & 0.1 & 1.1 \\
\hline Czech Republic & 58.5 & 53.3 & 5.0 & 22.8 & 0.0 & 0.0 & 0.0 & 7.3 & 12.4 & 0.0 & 2.2 & 0.2 & 3.3 & 0.1 & 0.3 & 0.0 & 0.1 & 0.0 & 2.4 \\
\hline Estonia & 94.0 & 91.9 & 0.7 & 0.4 & 0.0 & 0.0 & 13.5 & 0.1 & 7.4 & 0.0 & 0.7 & 0.4 & 0.4 & 0.0 & 0.0 & 68.8 & 0.1 & 0.0 & 0.2 \\
\hline Hungary & 56.9 & 48.7 & 3.9 & 8.5 & 0.3 & 0.0 & 0.0 & 2.1 & 24.2 & 0.0 & 6.4 & 0.5 & 2.5 & 0.0 & 0.2 & 0.0 & 0.6 & 0.8 & 2.9 \\
\hline Latvia & 37.7 & 36.2 & 0.3 & 0.1 & 0.0 & 0.0 & 6.1 & 0.1 & 8.4 & 0.0 & 0.1 & 0.1 & 0.1 & 0.0 & 0.0 & 21.0 & 0.1 & 0.0 & 0.2 \\
\hline Lithuania & 31.0 & 29.4 & 0.6 & 0.1 & 0.0 & 0.0 & 2.4 & 0.2 & 7.8 & 0.0 & 0.1 & 0.1 & 0.1 & 0.0 & 0.0 & 18.2 & 0.2 & 0.0 & 0.5 \\
\hline Poland & 39.1 & 31.2 & 1.9 & 3.8 & 0.1 & 0.0 & 0.1 & 0.9 & 12.1 & 0.0 & 6.9 & 0.4 & 4.0 & 0.0 & 0.1 & 1.0 & 0.3 & 0.4 & 3.2 \\
\hline Romania & 12.3 & 9.6 & 0.7 & 0.1 & 0.0 & 0.0 & 0.0 & 1.7 & 2.8 & 0.0 & 1.0 & 0.0 & 2.9 & 0.0 & 0.0 & 0.1 & 0.1 & 0.2 & 1.5 \\
\hline Slovak Republic & 47.2 & 43.4 & 3.7 & 6.8 & 0.0 & 0.0 & 0.0 & 1.4 & 7.9 & 0.0 & 19.6 & 0.4 & 3.5 & 0.0 & 0.0 & 0.3 & 0.5 & 0.3 & 2.3 \\
\hline Slovenia & 30.8 & 26.9 & 4.7 & 2.2 & 0.0 & 0.0 & 0.0 & 6.3 & 11.6 & 0.0 & 1.5 & 0.3 & 0.4 & 0.0 & 0.1 & 0.0 & 0.1 & 0.0 & 0.0 \\
\hline
\end{tabular}

Sources: BIS Consolidated Banking Statistics, third quarter 2003, January 2004, Table 9 and EBRD country database.

* EU-13 comprises the EU-15 countries minus Greece and Luxemburg, whose banks are not listed in the BIS Consolidated Banking Statistics. 
Annex 2: The 20 largest banks in the ACs

\begin{tabular}{|c|c|c|c|c|}
\hline Rank & Bank & Country & $\begin{array}{l}\text { Total assets in } \\
2002^{35}\end{array}$ & Main shareholder(s) \\
\hline 1 & $\begin{array}{l}\text { Powszechna Kasa } \\
\text { Oszczednosci Bank } \\
\text { Polski SA - PKO BP } \\
\text { SA }\end{array}$ & Poland & $\begin{array}{l}\text { PLN 82,018 million } \\
\text { (US\$ 20,102.5 } \\
\text { million) }\end{array}$ & 1. State of Poland (Poland) $100 \%$ \\
\hline 2 & $\begin{array}{l}\text { Ceskoslovenska } \\
\text { Obchodni Banka - } \\
\text { CSOB }\end{array}$ & $\begin{array}{l}\text { Czech } \\
\text { Republic }\end{array}$ & $\begin{array}{l}\text { CZK } 597,044.0 \\
\text { million } \\
\text { (US\$ } 18,236.5 \\
\text { million) }\end{array}$ & $\begin{array}{l}\text { 1. KBC Bank and Insurance Holding } 85.42 \% \text { (Belgium) } \\
\text { 2. EBRD } 7.47 \% \text { (IFI) } \\
\text { 3. IFC } 4.38(\mathrm{IFI})\end{array}$ \\
\hline 3 & Ceska Sporitelna a.s. & $\begin{array}{l}\text { Czech } \\
\text { Republic }\end{array}$ & $\begin{array}{l}\text { CZK 519,691 } \\
\text { million } \\
\text { (US\$ 15,873.8 } \\
\text { million) }\end{array}$ & $\begin{array}{l}\text { 1. Erste Bank der Oesterreichischen Sparkassen AG - } \\
\text { IAS } 94.80 \% \text { (Austria) }\end{array}$ \\
\hline 4 & $\begin{array}{l}\text { Bank Pekao SA-Bank } \\
\text { Polska Kasa Opieki SA }\end{array}$ & Poland & $\begin{array}{l}\text { PLN 65,084 million } \\
\text { (US\$ 15,951.96 } \\
\text { million) }\end{array}$ & $\begin{array}{l}\text { 1. Unicredito Italiano SPA (Italy) } 53.05 \% \\
\text { 2. State Treasury (Poland) } 4.13 \% \\
\text { 3. EBRD (IFI) } 3.31 \% \\
\text { 4. Allianz AG (Germany) } 2.13 \%\end{array}$ \\
\hline 5 & Komercni Banka & $\begin{array}{l}\text { Czech } \\
\text { Republic }\end{array}$ & $\begin{array}{l}\text { CZK 439,753 } \\
\text { million } \\
\text { (US\$ } 15,081.5 \\
\text { million) }\end{array}$ & $\begin{array}{l}\text { 1. Societe Generale (France) } 60.35 \% \\
\text { 2. The Bank of New York (US) } 5.46 \%\end{array}$ \\
\hline 6 & $\begin{array}{l}\text { Orszagos } \\
\text { Takarekpenztar es } \\
\text { Kereskedelmi - OTP } \\
\text { Bank }\end{array}$ & Hungary & $\begin{array}{l}\text { HUF } 2,719 \text { billion } \\
\text { (US } \$ 10,543.4 \\
\text { million) }\end{array}$ & $\begin{array}{l}\text { 1. Foreign institutional investors } 80.80 \% \\
\text { 2. Domestic institutional investors (Hungary) } 11.30 \% \\
\text { 3. Treasury (Hungary) } 4.90 \% \\
\text { 4. Management and Employees (Hungary) } 2.80 \% \\
\text { 5. State Budgetary Organisation (Hungary) } 0.10 \%\end{array}$ \\
\hline 7 & $\begin{array}{l}\text { Bank Przemyslowo- } \\
\text { Handlowy PBK SA }\end{array}$ & Poland & $\begin{array}{l}\text { PLN 45,095 million } \\
\text { (US } \$ 11,052.7 \text { ) }\end{array}$ & $\begin{array}{l}\text { 1. HVB/ Bank Austria Creditanstalt (Germany/Austria) } \\
71.08 \% \\
\text { 2. Bank of New York (US) } 4.04 \% \\
\text { 3. State Treasury (Poland) } 3.68 \%\end{array}$ \\
\hline 8 & $\begin{array}{l}\text { Nova Ljubljanska } \\
\text { Banka d.d. }\end{array}$ & Slovenia & $\begin{array}{l}\text { SIT } 1,980,481 \\
\text { million } \\
\text { (US\$ 8,243.4 } \\
\text { million) }\end{array}$ & $\begin{array}{l}\text { 1. State of Slovenia } 35.71 \% \\
\text { 2. KBC Bank NV (Belgium) } 34.00 \% \\
\text { 3. Slovenska Odskodninska Druzba d.d. (Slovenia) } \\
\text { 5.05\% } \\
\text { 4. Kapitalska Druzba d.d. - PPS (Slovenia) } 5.01 \% \\
\text { 5. EBRD (IFI) } 5.00 \%\end{array}$ \\
\hline 9 & $\begin{array}{l}\text { Bank Handlowy w } \\
\text { Warszawie S.A. }\end{array}$ & Poland & $\begin{array}{l}\text { PLN 32,182 million } \\
\text { (US\$ 7,887.8) }\end{array}$ & 1. Citibank (US) $93.20 \%$ \\
\hline 10 & $\begin{array}{l}\text { Ceska konsolidacni } \\
\text { agentura - CAS }\end{array}$ & $\begin{array}{l}\text { Czech } \\
\text { Republic }\end{array}$ & $\begin{array}{l}\text { CZK } 249,871 \\
\text { million } \\
\text { (US\$ 7,632.2 } \\
\text { million) }\end{array}$ & na \\
\hline 11 & BRE Bank SA & Poland & $\begin{array}{l}\text { PLN 27,432 million } \\
\text { (US } \$ 6,723.5 \\
\text { million) }\end{array}$ & $\begin{array}{l}\text { 1. Commerzbank AG (Germany) } 50.10 \% \\
\text { 2. Commercial Union OFE BPH CU WBK (Poland) } \\
>5.00 \% \\
\text { 3. Intesabci Holding International SA (Luxemburg) } \\
4.97 \%\end{array}$ \\
\hline 12 & $\begin{array}{l}\text { ING Bank Slaski S.A. - } \\
\text { Capital Group }\end{array}$ & Poland & $\begin{array}{l}\text { PLN 26,978 million } \\
\text { (US\$ 6,612.3 } \\
\text { million) }\end{array}$ & $\begin{array}{l}\text { 1. ING Groep NV (Netherlands) } 87.80 \% \\
\text { 2. Templeton Asset Management (US) } 7.20 \% \\
\text { 3. PTE Commercial Union (Poland) } 1.60 \%\end{array}$ \\
\hline 13 & $\begin{array}{l}\text { Bank Zachodni WBK } \\
\text { S.A. }\end{array}$ & Poland & $\begin{array}{l}\text { PLN 24,913 million } \\
\text { (US\$ 6,106.1 } \\
\text { million) }\end{array}$ & 1. AIB European Investments Limited (Ireland) $70.50 \%$ \\
\hline
\end{tabular}

${ }^{35}$ For converting the local currency amounts into US\$ the average exchange rates for 2002 were used. A ranking according to the resulting US\$ amounts would be slightly different from the BanksScope ranking. 
Annex 2 (continued): The 20 largest banks in the ACs

\begin{tabular}{|c|c|c|c|c|}
\hline 14 & Kredyt Bank & Poland & $\begin{array}{l}\text { PLN 24,061 million } \\
\text { (US\$ 5,897.3 } \\
\text { million) }\end{array}$ & 1. KBC Bank NV (Belgium) 81.40\% \\
\hline 15 & HansaPank & Estonia & $\begin{array}{l}\text { EEK 81,984 million } \\
\text { (US } \$ 4,935.2 \\
\text { million) }\end{array}$ & $\begin{array}{l}\text { 1. Foereningssparbanken - Swedbank (Sweden) } \\
\text { 59.70\% } \\
\text { 2. Nordea Bank Finland (Finland) } 5.80 \% \\
\text { 3. EBRD (IFI) } 4.80 \% \\
\text { 4. Chase (GB) } 3.30 \% \\
\text { 5. J.P. Morgan Bank Luxembourg SA (Luxembourg) } \\
\text { 2.40\% } \\
\text { 6. AS Suprema (n.a.) 1.60\% } \\
\text { 7. Skandinaviska Enskilda Banken AB (Sweden) } 1.50 \% \\
\text { 8. Pictet \& Cie (Switzerland) } 1.20 \% \\
\text { 9. Bank Austria Creditanstalt (Austria) } 1.10 \% \\
\text { 10. Raiffeisen Zentralbank Oesterreich AG (Austria) } \\
\text { 1.00\% }\end{array}$ \\
\hline 16 & $\begin{array}{l}\text { K\&H Bank- } \\
\text { Kereskedelmi es } \\
\text { Hitelbank RT }\end{array}$ & Hungary & $\begin{array}{l}\text { HUF } 1,235 \text { billion } \\
\text { (US } \$ 4,788.9 \\
\text { million) }\end{array}$ & $\begin{array}{l}\text { 1. KBC Bank NV (Belgium) } 59.01 \% \\
\text { 2. ABN Amro (Netherlands) } 40.22 \%\end{array}$ \\
\hline 17 & $\begin{array}{l}\text { Slovenska sporitel'na } \\
\text { as }\end{array}$ & $\begin{array}{l}\text { Slovak } \\
\text { Republic }\end{array}$ & $\begin{array}{l}\text { SKK } 205,037 \\
\text { million } \\
\text { (US\$ 4,523.5 } \\
\text { million) }\end{array}$ & $\begin{array}{l}\text { 1. Erste Bank der Oesterreichischen Sparkassen AG } \\
\text { (Austria) } 70.01 \% \\
\text { 2. EBRD (IFI) } 19.98 \% \\
\text { 3. Ministry of Finance (Slovak Republic) } 10.00 \%\end{array}$ \\
\hline 18 & Bank Millennium & Poland & $\begin{array}{l}\text { PLN 18,726 million } \\
\text { (US\$ 4,589.7 } \\
\text { million) }\end{array}$ & $\begin{array}{l}\text { 1. Banco Comercial Portugues, SA (Portugal) } 50.00 \% \\
\text { 2. EUREKO B.V. (Netherlands) } 19.98 \%\end{array}$ \\
\hline 19 & $\begin{array}{l}\text { Vseobecna Uverova } \\
\text { Banka a.s. }\end{array}$ & $\begin{array}{l}\text { Slovak } \\
\text { Republic }\end{array}$ & $\begin{array}{l}\text { SKK } 194,716 \\
\text { million } \\
\text { (US\$ 4,295.8 } \\
\text { million) }\end{array}$ & 1. Banca Intesa SPA (Italy) $94.47 \%$ \\
\hline 20 & $\begin{array}{l}\text { Bank Gospodarki } \\
\text { Zywnosciowej }\end{array}$ & Poland & $\begin{array}{l}\text { PLN 17,937 million } \\
\text { (US\$ 4,396.3 } \\
\text { million) }\end{array}$ & $\begin{array}{l}\text { 1. State Treasury (Poland) } 69.45 \% \\
\text { 2. Bank Polskiej Spoldzielczosci SA (Poland) } 16.59 \% \\
\text { 3. Gospodarczy Bank Wielkopolski S.A. (Poland) } 7.85 \% \\
\text { 4. Mazowiecki Bank Regionalny SA (Poland) } 3.78 \% \\
\text { 5. Banki Spolkdzielcze (Poland) } 1.93 \% \\
\text { 6. B.G.Z. SA (Poland) } 0.40 \%\end{array}$ \\
\hline
\end{tabular}

Source: BankScope (Bureau van Dijk), January 2004. 
Annex 3: Characteristics of the BEEPS dataset for ACs

\begin{tabular}{|c|c|c|c|}
\hline \multicolumn{2}{|l|}{ BULGARIA } & \multicolumn{2}{|l|}{ CZECH REPUBLIC } \\
\hline Total no. of observations & 250 & Total no. of observations & 268 \\
\hline Of which: & & Of which: & \\
\hline Urban (50,000 and above) & 156 & Urban (50,000 and above) & 151 \\
\hline Rural (under 50,000) & 94 & Rural (under 50,000) & 117 \\
\hline Small (2-49 employees) & 174 & Small (2-49 employees) & 179 \\
\hline Medium (50-249 employees) & 38 & Medium (50-249 employees) & 46 \\
\hline Large (250-9,999 employees) & 38 & Large (250-9,999 employees) & 43 \\
\hline ESTONIA & & HUNGARY & \\
\hline Total no. of observations & 170 & Total no. of observations & 250 \\
\hline Of which: & & Of which: & \\
\hline Urban (50,000 and above) & 128 & Urban (50,000 and above) & 196 \\
\hline Rural (under 50,000 ) & 42 & Rural (under 50,000) & 54 \\
\hline Small (2-49 employees) & 122 & Small (2-49 employees) & 170 \\
\hline Medium (50-249 employees) & 26 & Medium (50-249 employees) & 38 \\
\hline Large (250-9,999 employees) & 22 & Large (250-9,999 employees) & 42 \\
\hline LATVIA & & LITHUANIA & \\
\hline Total no. of observations & 176 & Total no. of observations & 200 \\
\hline Of which: & & Of which: & \\
\hline Urban (50,000 and above) & 121 & Urban (50,000 and above) & 133 \\
\hline Rural (under 50,000) & 55 & Rural (under 50,000) & 67 \\
\hline Small (2-49 employees) & 125 & Small (2-49 employees) & 134 \\
\hline Medium (50-249 employees) & 26 & Medium (50-249 employees) & 40 \\
\hline Large (250-9,999 employees) & 25 & Large (250-9,999 employees) & 26 \\
\hline POLAND & & ROMANIA & \\
\hline Total no. of observations & 500 & Total no. of observations & 255 \\
\hline Of which: & & Of which: & \\
\hline Urban (50,000 and above) & 378 & Urban (50,000 and above) & 174 \\
\hline Rural (under 50,000) & 122 & Rural (under 50,000) & 81 \\
\hline Small (2-49 employees) & 331 & Small (2-49 employees) & 154 \\
\hline Medium (50-249 employees) & 108 & Medium (50-249 employees) & 63 \\
\hline Large (250-9,999 employees) & 61 & Large (250-9,999 employees) & 38 \\
\hline SLOVAK REPUBLIC & & SLOVENIA & \\
\hline Total no. of observations & 170 & Total no. of observations & 188 \\
\hline Of which: & & Of which: & \\
\hline Urban (50,000 and above) & 139 & Urban (50,000 and above) & 89 \\
\hline Rural (under 50,000 ) & 31 & Rural (under 50,000 ) & 99 \\
\hline Small (2-49 employees) & 108 & Small (2-49 employees) & 144 \\
\hline Medium (50-249 employees) & 35 & Medium (50-249 employees) & 25 \\
\hline Large (250-9,999 employees) & 27 & Large (250-9,999 employees) & 19 \\
\hline
\end{tabular}




\section{Annex 4: Access to and cost of bank financing by country}

Average score by country on a scale of 1 (no obstacle), 2 (minor obstacle), 3 (moderate obstacle), 4 (major obstacle).

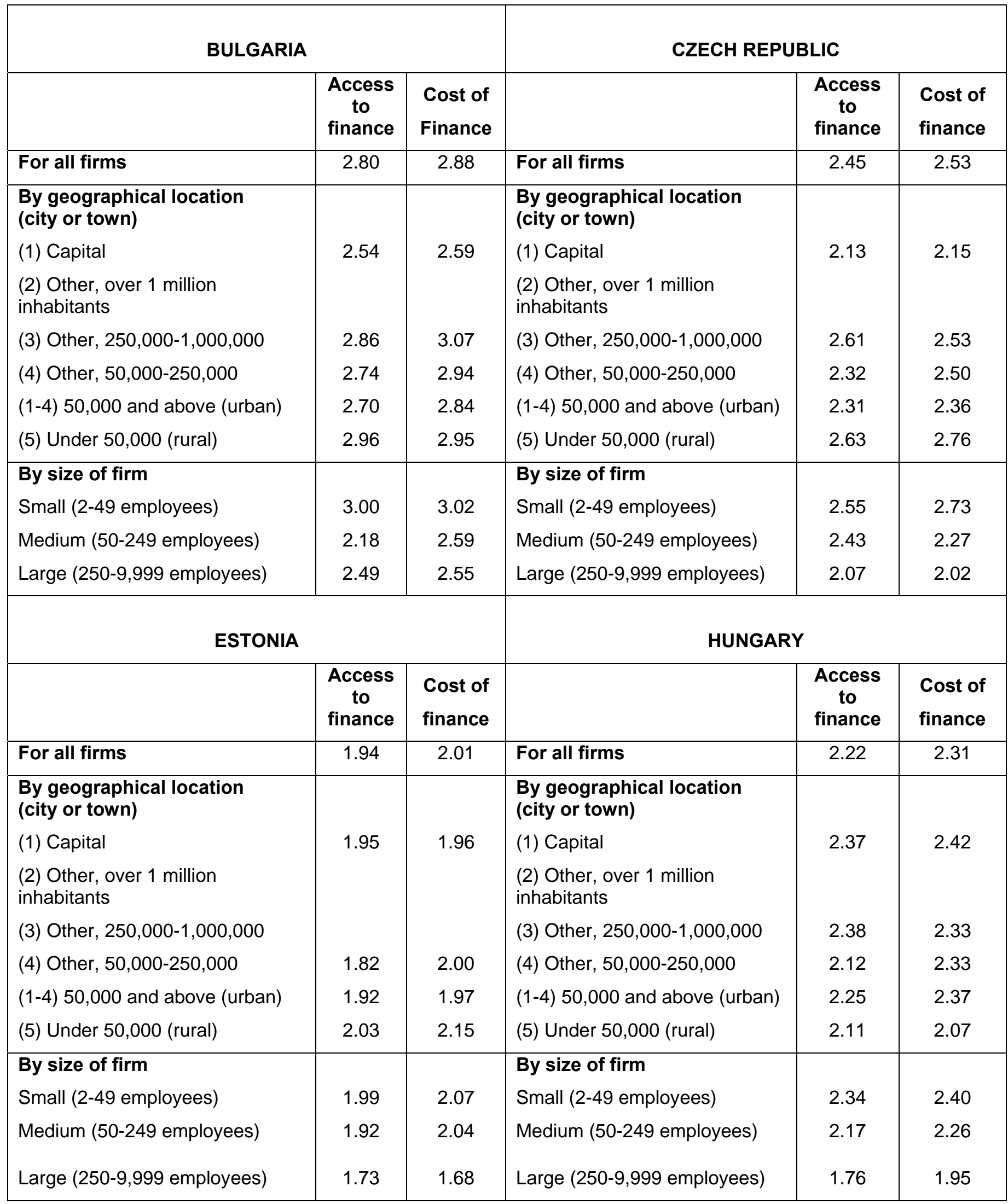

Source: Author's calculations with BEEPS 2002 dataset. 


\section{Annex 4 (continued): Access to and cost of bank financing by country}

Average score by country on a scale of 1 (no obstacle), 2 (minor obstacle), 3 (moderate obstacle), 4 (major obstacle).

\begin{tabular}{|c|c|c|c|c|c|}
\hline \multicolumn{3}{|l|}{ LATVIA } & \multicolumn{3}{|c|}{ LITHUANIA } \\
\hline & $\begin{array}{l}\text { Access } \\
\text { to } \\
\text { finance }\end{array}$ & $\begin{array}{l}\text { Cost of } \\
\text { finance }\end{array}$ & & $\begin{array}{l}\text { Access } \\
\text { to } \\
\text { finance }\end{array}$ & $\begin{array}{l}\text { Cost of } \\
\text { finance }\end{array}$ \\
\hline For all firms & 1.85 & 2.01 & For all firms & 1.62 & 1.99 \\
\hline $\begin{array}{l}\text { By geographical location } \\
\text { (city or town) }\end{array}$ & & & $\begin{array}{l}\text { By geographical location } \\
\text { (city or town) }\end{array}$ & & \\
\hline (1) Capital & 1.92 & 1.99 & (1) Capital & 1.68 & 2.16 \\
\hline $\begin{array}{l}\text { (2) Other, over } 1 \text { million } \\
\text { inhabitants }\end{array}$ & & & $\begin{array}{l}\text { (2) Other, over } 1 \text { million } \\
\text { inhabitants }\end{array}$ & & \\
\hline (3) Other, $250,000-1,000,000$ & & & (3) Other, $250,000-1,000,000$ & 1.10 & 1.65 \\
\hline (4) Other, 50,000-250,000 & 1.61 & 1.83 & (4) Other, $50,000-250,000$ & 1.63 & 1.68 \\
\hline (1-4) 50,000 and above (urban) & 1.87 & 1.97 & (1-4) 50,000 and above (urban) & 1.51 & 1.89 \\
\hline (5) Under 50,000 (rural) & 1.82 & 2.10 & (5) Under 50,000 (rural) & 1.81 & 2.18 \\
\hline By size of firm & & & By size of firm & & \\
\hline Small (2-49 employees) & 1.89 & 1.98 & Small (2-49 employees) & 1.68 & 1.97 \\
\hline Medium (50-249 employees) & 1.75 & 1.83 & Medium (50-249 employees) & 1.65 & 2.13 \\
\hline Large (250-9,999 employees) & 1.80 & 2.28 & Large (250-9,999 employees) & 1.22 & 1.88 \\
\hline \multicolumn{3}{|c|}{ POLAND } & \multicolumn{3}{|c|}{ ROMANIA } \\
\hline & $\begin{array}{l}\text { Access } \\
\text { to } \\
\text { finance }\end{array}$ & $\begin{array}{l}\text { Cost of } \\
\text { finance }\end{array}$ & & $\begin{array}{l}\text { Access } \\
\text { to } \\
\text { finance }\end{array}$ & $\begin{array}{l}\text { Cost of } \\
\text { finance }\end{array}$ \\
\hline For all firms & 2.65 & 3.17 & For all firms & 2.55 & 2.80 \\
\hline $\begin{array}{l}\text { By geographical location } \\
\text { (city or town) }\end{array}$ & & & $\begin{array}{l}\text { By geographical location } \\
\text { (city or town) }\end{array}$ & & \\
\hline (1) Capital & 2.46 & 2.97 & (1) Capital & 2.80 & 2.75 \\
\hline $\begin{array}{l}\text { (2) Other, over } 1 \text { million } \\
\text { inhabitants }\end{array}$ & 2.75 & 3.50 & $\begin{array}{l}\text { (2) Other, over } 1 \text { million } \\
\text { inhabitants }\end{array}$ & & \\
\hline (3) Other, $250,000-1,000,000$ & 2.75 & 3.20 & (3) Other, $250,000-1,000,000$ & 2.53 & 3.04 \\
\hline (4) Other, $50,000-250,000$ & 2.67 & 3.09 & (4) Other, $50,000-250,000$ & 2.12 & 2.42 \\
\hline (1-4) 50,000 and above (urban) & 2.68 & 3.14 & (1-4) 50,000 and above (urban) & 2.46 & 2.72 \\
\hline (5) Under 50,000 (rural) & 2.56 & 3.26 & (5) Under 50,000 (rural) & 2.74 & 2.99 \\
\hline By size of firm & & & By size of firm & & \\
\hline Small (2-49 employees) & 2.76 & 3.23 & Small (2-49 employees) & 2.63 & 2.90 \\
\hline Medium (50-249 employees) & 2.40 & 2.96 & Medium (50-249 employees) & 2.43 & 2.63 \\
\hline Large (250-9,999 employees) & 2.57 & 3.17 & Large (250-9,999 employees) & 2.41 & 2.70 \\
\hline
\end{tabular}

Source: Author's calculations with BEEPS 2002 dataset. 


\section{Annex 4 (continued): Access to and cost of bank financing by country}

Average score by country on a scale of 1 (no obstacle), 2 (minor obstacle), 3 (moderate obstacle), 4 (major obstacle).

\begin{tabular}{|c|c|c|c|c|c|}
\hline \multicolumn{3}{|c|}{ SLOVAK REPUBLIC } & \multicolumn{3}{|c|}{ SLOVENIA } \\
\hline & $\begin{array}{l}\text { Access } \\
\text { to } \\
\text { finance }\end{array}$ & $\begin{array}{l}\text { Cost of } \\
\text { finance }\end{array}$ & & $\begin{array}{l}\text { Access } \\
\text { to } \\
\text { finance }\end{array}$ & $\begin{array}{l}\text { Cost of } \\
\text { finance }\end{array}$ \\
\hline For all firms & 2.50 & 2.58 & For all firms & 1.82 & 2.20 \\
\hline $\begin{array}{l}\text { By geographical location } \\
\text { (city or town) }\end{array}$ & & & $\begin{array}{l}\text { By geographical location } \\
\text { (city or town) }\end{array}$ & & \\
\hline (1) Capital & 2.62 & 2.60 & (1) Capital & 1.75 & 1.76 \\
\hline $\begin{array}{l}\text { (2) Other, over } 1 \text { million } \\
\text { inhabitants }\end{array}$ & & & $\begin{array}{l}\text { (2) Other, over } 1 \text { million } \\
\text { inhabitants }\end{array}$ & & \\
\hline (3) Other, $250,000-1,000,000$ & & & (3) Other, $250,000-1,000,000$ & & \\
\hline (4) Other, 50,000-250,000 & 2.59 & 2.68 & (4) Other, 50,000-250,000 & 1.95 & 2.47 \\
\hline (1-4) 50,000 and above (urban) & 2.60 & 2.64 & (1-4) 50,000 and above (urban) & 1.84 & 2.07 \\
\hline (5) Under 50,000 (rural) & 2.03 & 2.32 & (5) Under 50,000 (rural) & 1.79 & 2.32 \\
\hline By size of firm & & & By size of firm & & \\
\hline Small (2-49 employees) & 2.57 & 2.68 & Small (2-49 employees) & 1.90 & 2.20 \\
\hline Medium (50-249 employees) & 2.45 & 2.47 & Medium (50-249 employees) & 1.72 & 2.40 \\
\hline Large (250-9,999 employees) & 2.24 & 2.35 & Large (250-9,999 employees) & 1.28 & 1.95 \\
\hline
\end{tabular}

Source: Author's calculations with BEEPS 2002 dataset. 
Annex 5: Access to short-term and long-term capital

Average score by country on a scale of 1 (impossible), 2 (very difficult), 3 (fairly difficult), 4 (fairly easy) to 5 (very easy).

\begin{tabular}{|c|c|c|c|c|c|}
\hline \multicolumn{3}{|c|}{ BULGARIA } & \multicolumn{3}{|c|}{ CZECH REPUBLIC } \\
\hline & $\begin{array}{c}\text { Short- } \\
\text { term } \\
\text { finance }\end{array}$ & $\begin{array}{l}\text { Long- } \\
\text { term } \\
\text { finance }\end{array}$ & & $\begin{array}{c}\text { Short- } \\
\text { term } \\
\text { finance }\end{array}$ & $\begin{array}{l}\text { Long- } \\
\text { term } \\
\text { finance }\end{array}$ \\
\hline For all firms & 2.77 & 2.56 & For all firms & 3.21 & 2.97 \\
\hline $\begin{array}{l}\text { By geographical location (city } \\
\text { or town) }\end{array}$ & & & $\begin{array}{l}\text { By geographical location } \\
\text { (city or town) }\end{array}$ & & \\
\hline (1) Capital & 3.35 & 2.94 & (1) Capital & 3.67 & 3.16 \\
\hline $\begin{array}{l}\text { (2) Other, over } 1 \text { million } \\
\text { inhabitants }\end{array}$ & & & $\begin{array}{l}\text { (2) Other, over } 1 \text { million } \\
\text { inhabitants }\end{array}$ & & \\
\hline (3) Other, $250,000-1,000,000$ & 2.83 & 2.55 & (3) Other, $250,000-1,000,000$ & 2.82 & 2.65 \\
\hline (4) Other, 50,000-250,000 & 2.60 & 2.53 & (4) Other, 50,000-250,000 & 3.24 & 3.00 \\
\hline (1-4) 50,000 and above (urban) & 2.94 & 2.68 & (1-4) 50,000 and above (urban) & 3.33 & 2.99 \\
\hline (5) Under 50,000 (rural) & 2.49 & 2.37 & (5) Under 50,000 (rural) & 3.05 & 2.95 \\
\hline By size of firm & & & By size of firm & & \\
\hline Small (2-49 employees) & 2.52 & 2.42 & Small (2-49 employees) & 2.99 & 2.77 \\
\hline Medium (50-249 employees) & 3.34 & 2.89 & Medium (50-249 employees) & 3.20 & 2.98 \\
\hline Large (250-9,999 employees) & 3.36 & 2.91 & Large (250-9,999 employees) & 4.02 & 3.71 \\
\hline \multicolumn{3}{|c|}{ ESTONIA } & \multicolumn{3}{|c|}{ HUNGARY } \\
\hline & $\begin{array}{l}\text { Short- } \\
\text { term } \\
\text { finance }\end{array}$ & $\begin{array}{l}\text { Long- } \\
\text { term } \\
\text { finance }\end{array}$ & & $\begin{array}{c}\text { Short- } \\
\text { term } \\
\text { finance }\end{array}$ & $\begin{array}{l}\text { Long- } \\
\text { term } \\
\text { finance }\end{array}$ \\
\hline For all firms & 3.88 & 3.63 & For all firms & 3.24 & 2.99 \\
\hline $\begin{array}{l}\text { By geographical location (city } \\
\text { or town) }\end{array}$ & & & $\begin{array}{l}\text { By geographical location } \\
\text { (city or town) }\end{array}$ & & \\
\hline (1) Capital & 4.11 & 3.82 & (1) Capital & 3.05 & 2.83 \\
\hline $\begin{array}{l}\text { (2) Other, over } 1 \text { million } \\
\text { inhabitants }\end{array}$ & & & $\begin{array}{l}\text { (2) Other, over } 1 \text { million } \\
\text { inhabitants }\end{array}$ & & \\
\hline (3) Other, $250,000-1,000,000$ & & & (3) Other, $250,000-1,000,000$ & 3.78 & 3.56 \\
\hline (4) Other, 50,000-250,000 & 3.69 & 3.66 & (4) Other, 50,000-250,000 & 3.38 & 3.05 \\
\hline (1-4) 50,000 and above (urban) & 3.98 & 3.77 & (1-4) 50,000 and above (urban) & 3.26 & 2.98 \\
\hline (5) Under 50,000 (rural) & 3.63 & 3.28 & (5) Under 50,000 (rural) & 3.19 & 3.02 \\
\hline By size of firm & & & By size of firm & & \\
\hline Small (2-49 employees) & 3.70 & 3.45 & Small (2-49 employees) & 3.04 & 2.79 \\
\hline Medium (50-249 employees) & 3.96 & 3.83 & Medium (50-249 employees) & 3.34 & 3.03 \\
\hline Large (250-9,999 employees) & 4.67 & 4.24 & Large (250-9,999 employees) & 3.95 & 3.71 \\
\hline
\end{tabular}

Source: Author's calculations with BEEPS 2002 dataset. 


\section{Annex 5 (continued): Access to short-term and long-term capital}

Average score by country on a scale of 1 (impossible), 2 (very difficult), 3 (fairly difficult), 4 (fairly easy) to 5 (very easy).

\begin{tabular}{|c|c|c|c|c|c|}
\hline \multicolumn{3}{|l|}{ LATVIA } & \multicolumn{3}{|c|}{ LITHUANIA } \\
\hline & $\begin{array}{l}\text { Short- } \\
\text { term } \\
\text { finance }\end{array}$ & $\begin{array}{c}\text { Long- } \\
\text { term } \\
\text { finance }\end{array}$ & & $\begin{array}{c}\text { Short- } \\
\text { term } \\
\text { finance }\end{array}$ & $\begin{array}{l}\text { Long- } \\
\text { term } \\
\text { finance }\end{array}$ \\
\hline For all firms & 3.28 & 2.99 & For all firms & 3.35 & 3.02 \\
\hline $\begin{array}{l}\text { By geographical location (city } \\
\text { or town) }\end{array}$ & & & $\begin{array}{l}\text { By geographical location } \\
\text { (city or town) }\end{array}$ & & \\
\hline (1) Capital & 3.22 & 2.89 & (1) Capital & 3.56 & 3.09 \\
\hline $\begin{array}{l}\text { (2) Other, over } 1 \text { million } \\
\text { inhabitants }\end{array}$ & & & $\begin{array}{l}\text { (2) Other, over } 1 \text { million } \\
\text { inhabitants }\end{array}$ & & \\
\hline (3) Other, $250,000-1,000,000$ & & & (3) Other, $250,000-1,000,000$ & 3.22 & 2.93 \\
\hline (4) Other, 50,000-250,000 & 3.80 & 3.53 & (4) Other, 50,000-250,000 & 3.31 & 3.11 \\
\hline (1-4) 50,000 and above (urban) & 3.30 & 2.98 & (1-4) 50,000 and above (urban) & 3.41 & 3.06 \\
\hline (5) Under 50,000 (rural) & 3.23 & 3.02 & (5) Under 50,000 (rural) & 3.24 & 2.95 \\
\hline By size of firm & & & By size of firm & & \\
\hline Small (2-49 employees) & 3.10 & 2.86 & Small (2-49 employees) & 3.20 & 2.86 \\
\hline Medium (50-249 employees) & 3.33 & 2.92 & Medium (50-249 employees) & 3.46 & 3.11 \\
\hline Large (250-9,999 employees) & 4.00 & 3.63 & Large (250-9,999 employees) & 3.88 & 3.68 \\
\hline \multicolumn{3}{|l|}{ POLAND } & \multicolumn{3}{|c|}{ ROMANIA } \\
\hline & $\begin{array}{l}\text { Short- } \\
\text { term } \\
\text { finance }\end{array}$ & $\begin{array}{l}\text { Long- } \\
\text { term } \\
\text { finance }\end{array}$ & & $\begin{array}{l}\text { Short- } \\
\text { term } \\
\text { finance }\end{array}$ & $\begin{array}{l}\text { Long- } \\
\text { term } \\
\text { finance }\end{array}$ \\
\hline For all firms & 3.29 & 3.06 & For all firms & 3.41 & 3.06 \\
\hline $\begin{array}{l}\text { By geographical location (city } \\
\text { or town) }\end{array}$ & & & $\begin{array}{l}\text { By geographical location } \\
\text { (city or town) }\end{array}$ & & \\
\hline (1) Capital & 3.33 & 3.08 & (1) Capital & 2.98 & 2.68 \\
\hline $\begin{array}{l}\text { (2) Other, over } 1 \text { million } \\
\text { inhabitants }\end{array}$ & 3.75 & 3.75 & $\begin{array}{l}\text { (2) Other, over } 1 \text { million } \\
\text { inhabitants }\end{array}$ & & \\
\hline (3) Other, $250,000-1,000,000$ & 3.18 & 2.92 & (3) Other, $250,000-1,000,000$ & 3.44 & 3.19 \\
\hline (4) Other, $50,000-250,000$ & 3.49 & 3.31 & (4) Other, 50,000-250,000 & 3.55 & 3.22 \\
\hline (1-4) 50,000 and above (urban) & 3.29 & 3.05 & (1-4) 50,000 and above (urban) & 3.37 & 3.07 \\
\hline (5) Under 50,000 (rural) & 3.28 & 3.07 & (5) Under 50,000 (rural) & 3.48 & 3.05 \\
\hline By size of firm & & & By size of firm & & \\
\hline Small (2-49 employees) & 3.13 & 2.92 & Small (2-49 employees) & 3.27 & 2.89 \\
\hline Medium (50-249 employees) & 3.64 & 3.43 & Medium (50-249 employees) & 3.67 & 3.33 \\
\hline Large (250-9,999 employees) & 3.44 & 3.08 & Large (250-9,999 employees) & 3.50 & 3.31 \\
\hline
\end{tabular}

Source: Author's calculations with BEEPS 2002 dataset. 
Annex 5 (continued): Access to short-term and long-term capital

Average score by country on a scale of 1 (impossible), 2 (very difficult), 3 (fairly difficult), 4 (fairly easy) to 5 (very easy).

\begin{tabular}{|c|c|c|c|c|c|}
\hline \multicolumn{3}{|c|}{ SLOVAK REPUBLIC } & \multicolumn{3}{|c|}{ SLOVENIA } \\
\hline & $\begin{array}{l}\text { Short- } \\
\text { term } \\
\text { finance }\end{array}$ & $\begin{array}{c}\text { Long- } \\
\text { term } \\
\text { finance }\end{array}$ & & $\begin{array}{l}\text { Short- } \\
\text { term } \\
\text { finance }\end{array}$ & $\begin{array}{l}\text { Long- } \\
\text { term } \\
\text { finance }\end{array}$ \\
\hline For all firms & 3.15 & 2.95 & For all firms & 3.97 & 3.70 \\
\hline $\begin{array}{l}\text { By geographical location (city } \\
\text { or town) }\end{array}$ & & & $\begin{array}{l}\text { By geographical location } \\
\text { (city or town) }\end{array}$ & & \\
\hline (1) Capital & 3.14 & 2.78 & (1) Capital & 3.84 & 3.67 \\
\hline $\begin{array}{l}\text { (2) Other, over } 1 \text { million } \\
\text { inhabitants }\end{array}$ & & & $\begin{array}{l}\text { (2) Other, over } 1 \text { million } \\
\text { inhabitants }\end{array}$ & & \\
\hline (3) Other, $250,000-1,000,000$ & & & (3) Other, $250,000-1,000,000$ & & \\
\hline (4) Other, $50,000-250,000$ & 3.03 & 2.91 & (4) Other, $50,000-250,000$ & 4.06 & 3.81 \\
\hline (1-4) 50,000 and above (urban) & 3.08 & 2.85 & (1-4) 50,000 and above (urban) & 3.93 & 3.72 \\
\hline (5) Under 50,000 (rural) & 3.43 & 3.33 & (5) Under 50,000 (rural) & 4.00 & 3.69 \\
\hline By size of firm & & & By size of firm & & \\
\hline Small (2-49 employees) & 3.08 & 2.88 & Small (2-49 employees) & 3.85 & 3.60 \\
\hline Medium (50-249 employees) & 3.15 & 2.85 & Medium (50-249 employees) & 4.29 & 3.83 \\
\hline Large (250-9,999 employees) & 3.46 & 3.33 & Large (250-9,999 employees) & 4.41 & 4.38 \\
\hline
\end{tabular}

Source: Author's calculations with BEEPS 2002 dataset. 
Annex 6: Sources of finance, by country and size of firm (in per cent)

\begin{tabular}{|c|c|c|c|c|c|c|}
\hline \multicolumn{7}{|c|}{ BULGARIA } \\
\hline & \multicolumn{2}{|c|}{ Large firms } & \multicolumn{2}{|c|}{ Medium firms } & \multicolumn{2}{|c|}{ Small firms } \\
\hline & $\begin{array}{l}\text { Working } \\
\text { capital }\end{array}$ & $\begin{array}{c}\text { New } \\
\text { investment }\end{array}$ & $\begin{array}{l}\text { Working } \\
\text { capital }\end{array}$ & $\begin{array}{c}\text { New } \\
\text { investment }\end{array}$ & $\begin{array}{l}\text { Working } \\
\text { capital }\end{array}$ & $\begin{array}{c}\text { New } \\
\text { investment }\end{array}$ \\
\hline Internal funds/retained earnings & 53.03 & 50.53 & 62.24 & 46.18 & 68.55 & 50.49 \\
\hline Borrowing from local private commercial banks & 9.37 & 13.68 & 7.16 & 7.37 & 2.87 & 1.49 \\
\hline $\begin{array}{l}\text { Borrowing from state-owned banks, including } \\
\text { state development banks }\end{array}$ & 3.42 & 1.84 & 1.32 & 1.32 & 5.29 & 3.28 \\
\hline Borrowing from foreign banks & 3.95 & 3.42 & 3.68 & 1.32 & 0.60 & 0.98 \\
\hline Trade credit from suppliers & 11.45 & 1.58 & 6.05 & 2.50 & 6.50 & 0.72 \\
\hline Trade credit from customers & 2.68 & 2.63 & 3.29 & 0.00 & 0.78 & 0.00 \\
\hline Credit cards & 0.00 & 0.00 & 0.00 & 0.00 & 0.00 & 0.00 \\
\hline Leasing arrangement & 3.47 & 6.32 & 0.55 & 4.47 & 0.95 & 1.21 \\
\hline Government (other than state-owned banks) & 9.74 & 9.47 & 7.29 & 5.26 & 1.90 & 0.75 \\
\hline Other & 0.00 & 0.00 & 5.53 & 5.26 & 1.15 & 1.15 \\
\hline Total & 97.37 & 89.47 & 97.37 & 73.68 & 99.99 & 67.26 \\
\hline \multicolumn{7}{|c|}{ CZECH REPUBLIC } \\
\hline Borrowing from local private commercial banks & 9.65 & 8.74 & 6.96 & 4.46 & 4.63 & 5.00 \\
\hline $\begin{array}{l}\text { Borrowing from state-owned banks, including } \\
\text { state development banks }\end{array}$ & 6.51 & 3.26 & 4.35 & 4.35 & 1.56 & 3.83 \\
\hline Borrowing from foreign banks & 5.81 & 10.23 & 1.09 & 3.26 & 0.56 & 0.56 \\
\hline Loans from family/friends & 2.56 & 1.40 & 0.65 & 0.00 & 5.37 & 3.72 \\
\hline $\begin{array}{l}\text { Money lenders or other informal sources (other } \\
\text { than family/friends) }\end{array}$ & 1.16 & 0.00 & 1.30 & 0.00 & 2.68 & 2.77 \\
\hline Trade credit from suppliers & 5.53 & 2.49 & 6.09 & 1.96 & 6.44 & 2.65 \\
\hline Trade credit from customers & 0.47 & 0.00 & 1.09 & 1.09 & 1.26 & 0.42 \\
\hline Credit cards & 0.53 & 0.00 & 0.00 & 0.00 & 2.74 & 1.82 \\
\hline Leasing arrangement & 3.51 & 10.65 & 4.07 & 9.02 & 2.99 & 8.87 \\
\hline Government (other than state-owned banks) & 0.23 & 1.86 & 4.35 & 7.28 & 1.90 & 2.11 \\
\hline Other & 1.60 & 1.56 & 9.67 & 7.61 & 3.02 & 3.80 \\
\hline Total & 86.02 & 86.05 & 91.32 & 86.96 & 96.64 & 89.40 \\
\hline
\end{tabular}

Source: Author's calculations with BEEPS 2002 dataset. 
Annex 6 (continued): Sources of finance, by country and size of firm (in per cent)

\begin{tabular}{|c|c|c|c|c|c|c|}
\hline \multicolumn{7}{|c|}{ ESTONIA } \\
\hline & \multicolumn{2}{|c|}{ Large firms } & \multicolumn{2}{|c|}{ Medium firms } & \multicolumn{2}{|c|}{ Small firms } \\
\hline & $\begin{array}{l}\text { Working } \\
\text { capital }\end{array}$ & $\begin{array}{c}\text { New } \\
\text { investment }\end{array}$ & $\begin{array}{l}\text { Working } \\
\text { capital }\end{array}$ & $\begin{array}{c}\mathrm{New} \\
\text { investment }\end{array}$ & $\begin{array}{l}\text { Working } \\
\text { capital }\end{array}$ & $\begin{array}{c}\text { New } \\
\text { investment }\end{array}$ \\
\hline Internal funds/retained earnings & 66.59 & 59.09 & 73.85 & 64.81 & 69.71 & 36.96 \\
\hline Equity (i.e. issue of new shares) & 0.00 & 0.00 & 3.85 & 3.85 & 1.48 & 1.80 \\
\hline Borrowing from local private commercial banks & 6.14 & 6.45 & 9.58 & 11.50 & 3.97 & 4.31 \\
\hline $\begin{array}{l}\text { Borrowing from state-owned banks, including state } \\
\text { development banks }\end{array}$ & 0.00 & 0.00 & 0.00 & 0.00 & 1.07 & 0.00 \\
\hline Borrowing from foreign banks & 3.64 & 3.64 & 0.00 & 0.00 & 0.00 & 0.00 \\
\hline Loans from family/friends & 4.55 & 4.55 & 0.19 & 0.38 & 2.55 & 0.82 \\
\hline $\begin{array}{l}\text { Money lenders or other informal sources (other } \\
\text { than family/friends) }\end{array}$ & 1.34 & 0.00 & 1.15 & 0.00 & 0.57 & 0.66 \\
\hline Trade credit from suppliers & 3.18 & 1.36 & 8.27 & 0.38 & 6.01 & 1.31 \\
\hline Trade credit from customers & 0.23 & 0.45 & 0.00 & 0.00 & 2.13 & 0.00 \\
\hline Credit cards & 0.00 & 0.00 & 0.19 & 0.00 & 0.16 & 0.82 \\
\hline Leasing arrangement & 4.09 & 14.00 & 2.92 & 7.54 & 3.98 & 16.72 \\
\hline Government (other than state-owned banks) & 3.18 & 0.00 & 0.00 & 0.00 & 0.00 & 0.00 \\
\hline Other & 2.50 & 5.91 & 0.00 & 0.00 & 3.45 & 2.17 \\
\hline Total & 95.44 & 95.45 & 100.00 & 88.46 & 95.08 & 65.57 \\
\hline \multicolumn{7}{|c|}{ HUNGARY } \\
\hline & \multicolumn{2}{|c|}{ Large firms } & \multicolumn{2}{|c|}{ Medium firms } & \multicolumn{2}{|c|}{ Small firms } \\
\hline & $\begin{array}{l}\text { Working } \\
\text { capital }\end{array}$ & $\begin{array}{c}\text { New } \\
\text { investment }\end{array}$ & $\begin{array}{l}\text { Working } \\
\text { capital }\end{array}$ & $\begin{array}{c}\mathrm{New} \\
\text { investment }\end{array}$ & $\begin{array}{l}\text { Working } \\
\text { capital }\end{array}$ & $\begin{array}{c}\mathrm{New} \\
\text { investment }\end{array}$ \\
\hline Internal funds/retained earnings & 57.52 & 40.00 & 48.82 & 44.47 & 66.87 & 51.34 \\
\hline Equity (i.e. issue of new shares) & 7.86 & 6.43 & 12.50 & 15.79 & 16.23 & 13.46 \\
\hline Borrowing from local private commercial banks & 13.88 & 19.05 & 15.39 & 10.66 & 3.22 & 3.88 \\
\hline $\begin{array}{l}\text { Borrowing from state-owned banks, including state } \\
\text { development banks }\end{array}$ & 2.86 & 7.26 & 7.24 & 4.87 & 2.92 & 5.82 \\
\hline Borrowing from foreign banks & 2.38 & 2.38 & 2.11 & 0.00 & 0.00 & 0.41 \\
\hline Loans from family/friends & 0.00 & 0.00 & 1.58 & 3.16 & 3.07 & 2.56 \\
\hline $\begin{array}{l}\text { Money lenders or other informal sources (other } \\
\text { than family/friends) }\end{array}$ & 0.00 & 0.00 & 0.00 & 0.00 & 0.12 & 0.00 \\
\hline Trade credit from suppliers & 5.62 & 0.12 & 6.32 & 0.79 & 2.35 & 0.85 \\
\hline Trade credit from customers & 1.55 & 1.79 & 0.00 & 0.00 & 0.59 & 0.75 \\
\hline Credit cards & 0.00 & 0.00 & 0.00 & 0.00 & 0.76 & 0.12 \\
\hline Leasing arrangement & 0.00 & 1.31 & 0.79 & 3.55 & 1.58 & 2.96 \\
\hline Government (other than state-owned banks) & 2.50 & 2.86 & 1.32 & 0.92 & 0.41 & 0.62 \\
\hline Other & 1.07 & 2.14 & 3.95 & 2.63 & 0.71 & 0.62 \\
\hline Total & 95.24 & 83.34 & 100.02 & 86.84 & 98.83 & 83.39 \\
\hline
\end{tabular}

Source: Author's calculations with BEEPS 2002 dataset. 
Annex 6 (continued): Sources of finance, by country and size of firm (in per cent)

\begin{tabular}{|c|c|c|c|c|c|c|}
\hline \multicolumn{7}{|c|}{ LATVIA } \\
\hline & \multicolumn{2}{|c|}{ Large firms } & \multicolumn{2}{|c|}{ Medium firms } & \multicolumn{2}{|c|}{ Small firms } \\
\hline & $\begin{array}{l}\text { Working } \\
\text { capital }\end{array}$ & $\begin{array}{c}\text { New } \\
\text { investment }\end{array}$ & $\begin{array}{l}\text { Working } \\
\text { capital }\end{array}$ & $\begin{array}{c}\text { New } \\
\text { investment }\end{array}$ & $\begin{array}{l}\text { Working } \\
\text { capital }\end{array}$ & $\begin{array}{c}\text { New } \\
\text { investment }\end{array}$ \\
\hline Internal funds/retained earnings & 28.52 & 23.40 & 43.96 & 19.81 & 44.63 & 18.98 \\
\hline Borrowing from local private commercial banks & 7.72 & 18.60 & 5.19 & 12.31 & 2.72 & 1.28 \\
\hline $\begin{array}{l}\text { Borrowing from state-owned banks, including state } \\
\text { development banks }\end{array}$ & 2.92 & 2.00 & 2.42 & 0.77 & 0.52 & 1.40 \\
\hline Borrowing from foreign banks & 0.20 & 0.00 & 1.23 & 1.92 & 0.23 & 0.06 \\
\hline Trade credit from suppliers & 10.44 & 0.00 & 10.81 & 3.65 & 9.43 & 1.04 \\
\hline Trade credit from customers & 2.92 & 1.20 & 3.23 & 0.00 & 4.73 & 0.18 \\
\hline Credit cards & 0.20 & 0.00 & 0.40 & 0.19 & 0.36 & 1.24 \\
\hline Leasing arrangement & 2.28 & 2.00 & 0.73 & 0.58 & 2.06 & 2.12 \\
\hline Government (other than state-owned banks) & 0.00 & 0.00 & 1.27 & 4.23 & 1.08 & 0.92 \\
\hline Other & 0.48 & 4.00 & 9.88 & 3.08 & 5.52 & 2.45 \\
\hline Total & 80.00 & 56.00 & 96.50 & 53.84 & 94.39 & 39.20 \\
\hline \multicolumn{7}{|c|}{ LITHUANIA } \\
\hline Borrowing from local private commercial banks & 13.15 & 10.35 & 12.00 & 6.00 & 3.20 & 2.20 \\
\hline $\begin{array}{l}\text { Borrowing from state-owned banks, including state } \\
\text { development banks }\end{array}$ & 1.54 & 3.08 & 0.00 & 0.00 & 0.82 & 0.82 \\
\hline Borrowing from foreign banks & 0.00 & 2.04 & 0.03 & 0.00 & 0.00 & 0.00 \\
\hline Loans from family/friends & 0.00 & 0.00 & 0.13 & 0.00 & 2.13 & 3.13 \\
\hline $\begin{array}{l}\text { Money lenders or other informal sources (other } \\
\text { than family/friends) }\end{array}$ & 0.00 & 0.00 & 0.25 & 0.00 & 0.99 & 0.62 \\
\hline Trade credit from suppliers & 7.50 & 5.58 & 7.75 & 2.50 & 5.93 & 0.45 \\
\hline Trade credit from customers & 6.54 & 1.92 & 1.45 & 0.00 & 2.48 & 0.30 \\
\hline Credit cards & 0.00 & 0.00 & 0.00 & 0.00 & 0.15 & 0.00 \\
\hline Leasing arrangement & 7.12 & 10.96 & 2.20 & 10.58 & 2.24 & 4.58 \\
\hline Government (other than state-owned banks) & 0.00 & 0.00 & 0.00 & 0.00 & 1.68 & 1.49 \\
\hline Other & 0.04 & 2.69 & 5.30 & 5.00 & 2.13 & 2.60 \\
\hline Total & 96.15 & 80.77 & 97.51 & 75.01 & 99.26 & 74.62 \\
\hline
\end{tabular}

Source: Author's calculations with BEEPS 2002 dataset. 
Annex 6 (continued): Sources of finance, by country and size of firm (in per cent)

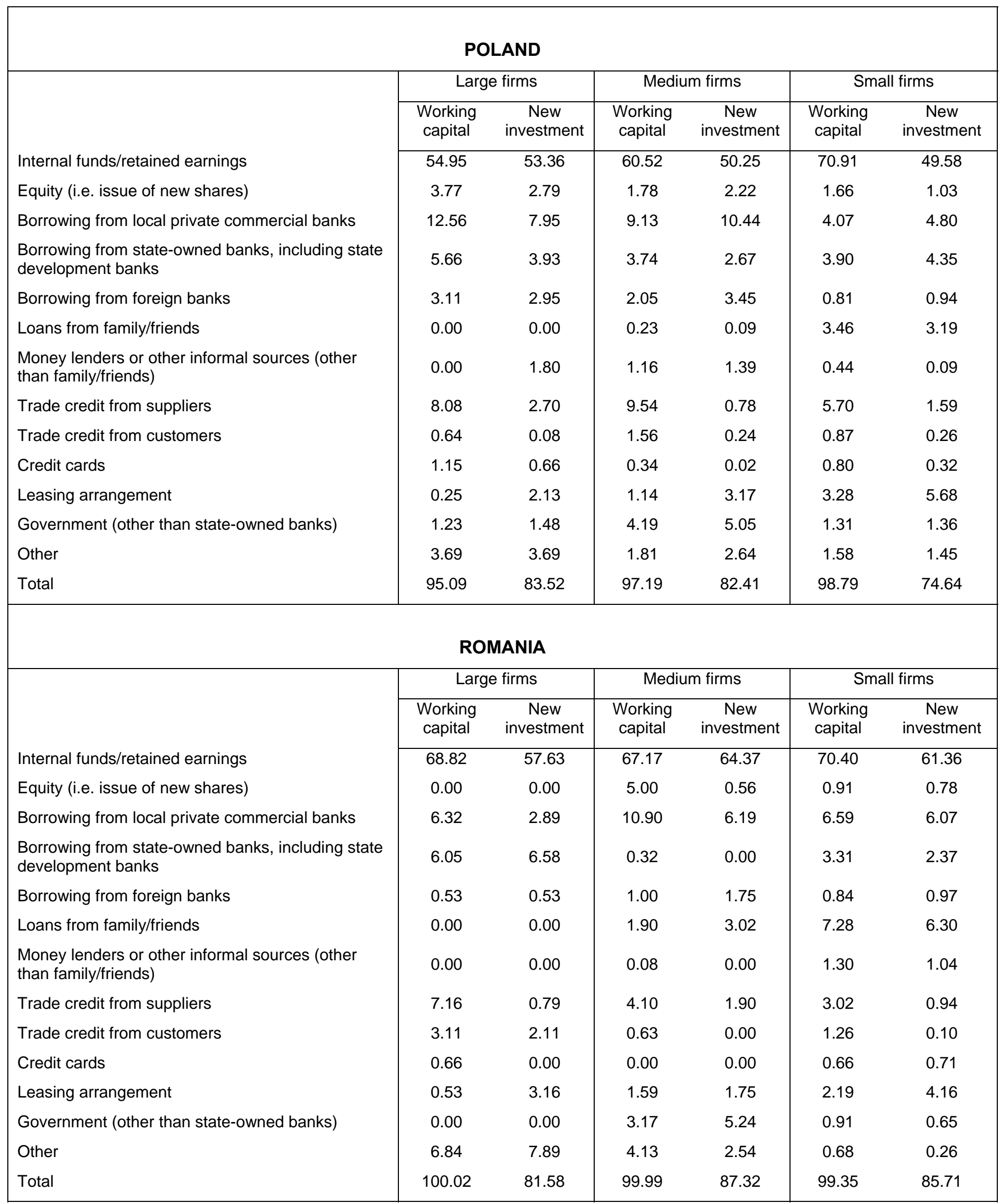

Source: Author's calculations with BEEPS 2002 dataset. 
Annex 6 (continued): Sources of finance, by country and size of firm (in per cent)

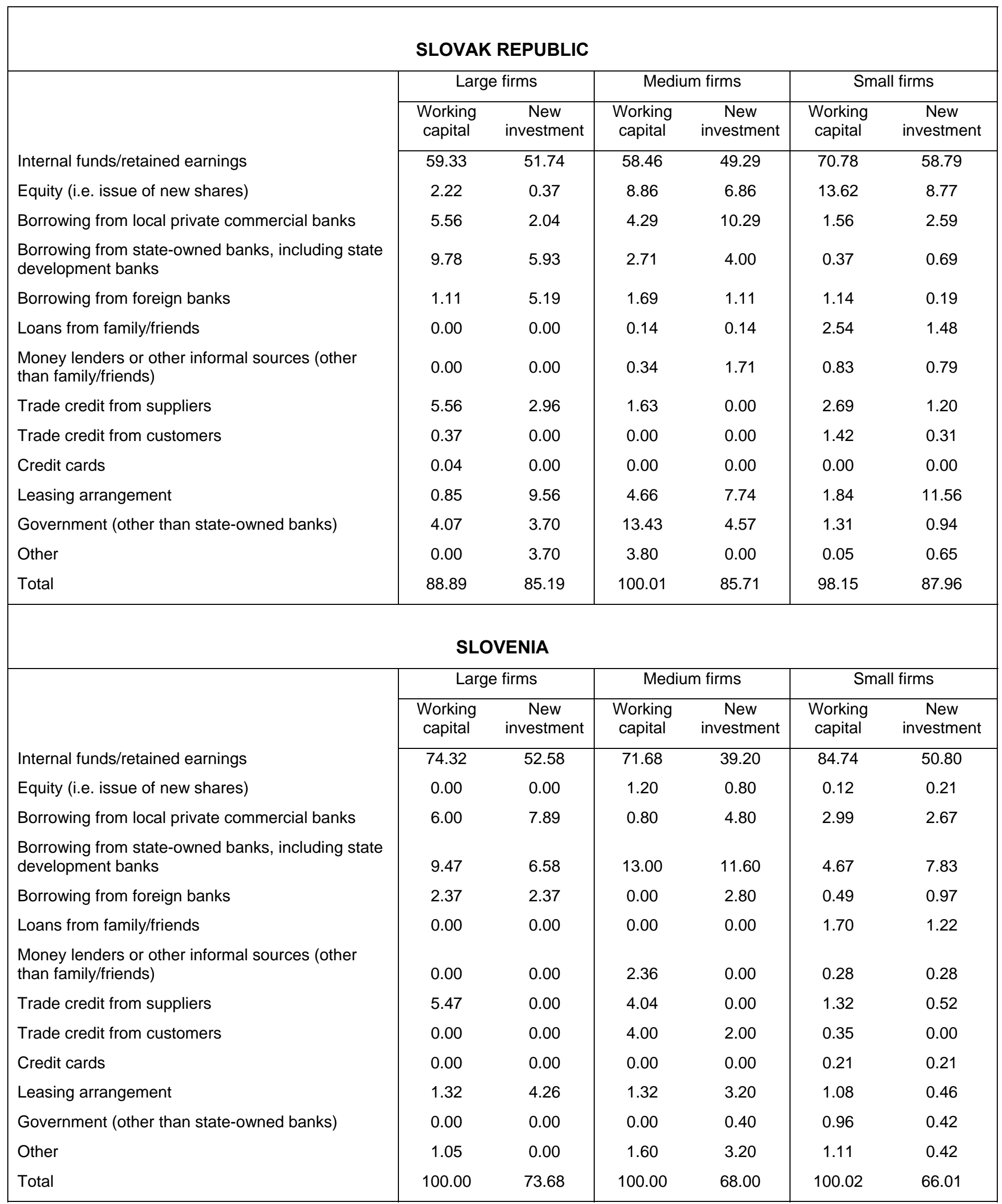

Source: Author's calculations with BEEPS 2002 dataset. 